\title{
Production of microbial lipids utilizing volatile fatty acids derived from wastepaper: A
} biorefinery approach for biodiesel production

Neelamegam Annamalai ${ }^{1,2^{*}}$, Nallusamy Sivakumar ${ }^{2}$, Alfred Fernandez-Castane ${ }^{3,4}$ and Piotr Oleskowicz-Popiel ${ }^{5}$

${ }^{1}$ Hawaii Natural Energy Institute, University of Hawaii at Manoa, 1680, East-West Road, Honolulu - 96822, HI, USA

${ }^{2}$ Department of Biology, College of Science, Sultan Qaboos University, PO Box 36, Muscat 123, Oman

${ }^{3}$ Aston Institute of Materials Research, Aston University, Birmingham, B4 7ET, UK ${ }^{4}$ Energy and Bioproducts Research Institute, Aston University, Birmingham, B4 7ET, UK ${ }^{5}$ Water Supply and Bioeconomy Division, Faculty of Environmental Engineering and Energy, Poznan University of Technology, Berdychowo 4, 60-965, Poznan, Poland

\section{Abstract}

Volatile fatty acids (VFAs) derived from organic wastes are being considered as low-cost feedstock for microbial lipid production as a valuable alternative to plant derived oils/biodiesel. In this study, VFAs were produced from anaerobic open culture fermentation of wastepaper and subsequently, used as feedstock for lipid production by Cryptococcus curvatus. Total VFAs, yield and productivity achieved from waste office paper (WOP) and newspaper (WNP) were 17.3 and $10.2 \mathrm{~g} / \mathrm{L}, 0.17$ and $0.10 \mathrm{~g} / \mathrm{g}$ TS, and 0.86 and $0.51 \mathrm{~g} / \mathrm{L} / \mathrm{day}$, respectively. Biomass, lipid content and productivity achieved utilizing VFAs of WOP and WNP were 4.3 and $2.9 \mathrm{~g} / \mathrm{L}, 41.2$ and $27.7 \% \mathrm{DCW}$, and 0.037 and $0.033 \mathrm{~g} / \mathrm{L} / \mathrm{h}$, respectively. The dominance of fatty acids such as oleic, palmitic, stearic and linoleic acid in the lipids suggests a high level of similarity with plant/vegetable oils used for biodiesel production. Therefore, VFAs derived from wastepaper could be potentially used as feedstock to produce microbial lipids towards cost-effective production of biodiesel.

Keywords: Biodiesel; Volatile fatty acids; Wastepaper; Anaerobic open culture fermentation; Oleaginous yeast; Microbial lipids.

*Corresponding Authors: Neelamegam Annamalai, Email: annabact@gmail.com, Tel.: +1 8086836910 


\section{Introduction}

Currently, the world is facing global challenges such as fossil fuel depletion and climate change caused by global warming due to the increase of greenhouse gasses (GHGs) emissions

34 from fossil fuels $[1,2]$. Biodiesel, fatty acids alkyl ester, can be obtained by transesterification of triacylglycerol from edible vegetable oils (i.e. soybean, sunflower and palm oil), fats and cooling oil wastes, has several advantages than conventional petroleum-based diesel fuel such as non-

37 sulfur oxide emission, sustainability and potential for carbon reduction [3]. However, the use of these edible oils as a feedstock for biodiesel limiting its commercialization as it competes with food production and increase the cost of raw material such as vegetables and agricultural commodities [4]. Microbial lipids produced by oleaginous microorganisms, which accumulates $20-80 \%$ of their dry weight in the form of lipids under nutrient-limitation conditions, are the most promising alternative non-edible lipid source for sustainable production of biodiesel [5-8].

43 However, the production cost of microbial lipids remains as a major limiting factor due to the 44 carbon sources used for production, which is estimated to be about $80 \%$ of the total medium cost and it contributes to over $60 \%$ of the total production costs while using glucose as a carbon

46 source [9]. A potential solution to reduce the production cost is to utilize low-cost or waste

47 biomass that can be used as a substrate for microbial lipid production $[8,10,11]$.

Volatile fatty acids (VFAs) are linear short-chain fatty acids (C2 - C5), which includes 49 acetic, propionic, butyric, isobutyric, valeric, isovaleric and 2-methylbutyric acid are 50 intermediate products of anaerobic digestion (AD), have been extensively investigated for 51 production of various bio-based materials, using a so-called VFAs platform [12-14]. The major 52 advantages of VFAs platform for bio-based materials production are the absence of requirement 53 for sterilization or addition of enzymes to hydrolyze, and the availability of feedstock in 
54 substantial quantities [15].VFAs are considered as a potential carbon source for lipid production

55 using oleaginous yeast as it requires only shorter transformation pathway (VFAs into acetyl-

56 CoA, which is used for biosynthesis of lipids) with high theoretical lipid conversion efficiency

$57[16,17]$.

Microbial lipids production utilizing lignocellulosic biomass has received increasing 59 interest in recent days, as an alternative solution for large-scale production of biodiesel [7, 18, 19]. Wastepaper, a major component of municipal and industrial solid wastes, accounts more

61 than $35 \%$ of total lignocellulosic wastes is being considered as a promising feedstock for biofuels

62 due to its sustainability and abundance [20,21]. Recently, wastepaper has been used as feedstock

63 for production of various valuable bio-products such as bioethanol and PHAs [7, 20, 22].

64 Utilization of wastepaper for production of microbial lipids is a promising alternative biorefinery

65 approach for large-scale production of biodiesel, which is not only reduces the cost of 66 production, but also provides alternative route for waste management [23]. Hence, in this study 67 we aim to investigate the conversion of wastepaper into VFAs through anaerobic open culture 68 fermentation (OCF) and subsequently, use the VFAs as possible feedstock for production of 69 microbial lipids as an alternative to industrial production of biodiesel.

\section{2. Materials and methods}

All chemicals and reagents used in this study were purchased from Sigma-Aldrich (St.

72 Louis, MO, USA) or as indicated.

\section{2.1. Inocula}

74 2.1.1. Inoculum for VFAs production

Waste activated sludge (WAS) obtained from local wastewater treatment plant was 76 passed through a sieve ( $18 \mathrm{mesh})$ and heat treated at $90^{\circ} \mathrm{C}$ for $20 \mathrm{~min}$ to inactivate methanogens. 
77 The raw sludge contained $1.59 \pm 0.01 \mathrm{~g} / \mathrm{L}$ total suspended solid (TSS) and $1.36 \pm 0.01 \mathrm{~g} / \mathrm{L}$

78 volatile suspended solid (VSS). Further, WAS purged with $\mathrm{N}_{2}$ gas for $10 \mathrm{~min}, \mathrm{pH}$ maintained at

$795.4-5.6$ using $2 \mathrm{~N} \mathrm{HCl}$ and $\mathrm{NaOH}$, incubated in a shaker incubator at $35^{\circ} \mathrm{C}$ and $200 \mathrm{rpm}$ was

80 used as a inoculum for VFA production.

81

82

83

84

85

86

87

88

\subsubsection{Inoculum for microbial lipid production}

The oleaginous yeast, Cryptococcus curvatus DSM 70022 obtained from DSMZ (Germany) was propagated on YPD agar slants in every two weeks (yeast extract 10; peptone 10; glucose 20; agar 15 (g/L), pH 6.0, 30 ${ }^{\circ}$ C). For seed culture, C. curvatus was inoculated into 50 $\mathrm{mL}$ of YPD medium in $250 \mathrm{~mL}$ flask and incubated at $30^{\circ} \mathrm{C}, 200 \mathrm{rpm}$ for $36 \mathrm{~h}$. Afterwards, the cultures were grown in a medium containing $10 \mathrm{~g} / \mathrm{L}$ acetate, $2 \mathrm{~g} / \mathrm{L}$ propionate, $1 \mathrm{~g} / \mathrm{L}$ butyrate, 1 $\mathrm{g} / \mathrm{L}$ peptone, and $1 \mathrm{~g} / \mathrm{L}$ yeast extract $(\mathrm{pH}-5.5)$ for $24 \mathrm{~h}$ and used as a inoculum for lipid production.

\subsection{Feasibility of C. curvatus for lipid production using VFAs}

The feasibility of C. curavtus for lipid production using VFAs was investigated using synthetic VFAs [mixture of acetic acid (AA), propionic acid (PA) and butyric acid (BA)]. The influence of VFAs on lipid accumulation was studied by comparing the initial concentration and ratio of each VFA in the mixture. The effect of initial VFAs concentration was evaluated using 2, 5 and $10 \mathrm{~g} / \mathrm{L}$ at a ratio of 5:1:4. Effects of various VFAs ratio (AA: BA: PA) (5:1:4, 5:2:3, 6:2:2 and 6:1:3) on lipid accumulation was investigated at an initial concentration of $5 \mathrm{~g} / \mathrm{L}$ VFAs. The effect of various nitrogen sources and their combination (1:1) on lipid production was investigated using various inorganic $\left[\left(\mathrm{NH}_{4}\right)_{2} \mathrm{SO}_{4}, \mathrm{NH}_{4} \mathrm{Cl}, \mathrm{NH}_{4} \mathrm{NO}_{3}, \mathrm{NaNO}_{3}\right.$ and $\left.\mathrm{KNO}_{3}\right]$ and organic nitrogen sources [yeast extract $(10 \% \mathrm{~N}, \mathrm{w} / \mathrm{w})$ ] and peptone $(14 \% \mathrm{~N}, \mathrm{w} / \mathrm{w})$ ]. The initial 
$99 \mathrm{pH}$ of the medium was adjusted to 5.5 using $2 \mathrm{~N} \mathrm{HCl}$ and $\mathrm{NaOH}$, and the $\mathrm{C} / \mathrm{N}$ ratio was 100 maintained at 40 under all tested concentrations.

101

102

103

104

105

106

107

108

109

110

111

112

113

114

115

116

117

118

119

120

\subsection{Feedstock pretreatment for VFAs production}

The feedstock for VFAs production such as waste office paper (WOP) and waste newspaper (WNP) were shredded into a small pieces $(2 \times 6 \mathrm{~mm})$ and subjected to pretreatment by mixing with $0.5 \% \mathrm{H}_{2} \mathrm{O}_{2}(5 \% \mathrm{w} / \mathrm{v})$ and then autoclave at $121^{\circ} \mathrm{C}$ for $30 \mathrm{~min}$. The solid residue was collected by centrifugation (Eppendorf-5810R, Germany) at $5000 x g$ for $10 \mathrm{~min}$, washed 3 4 times repeatedly with deionized water until obtain neutral $\mathrm{pH}$, dried at $60^{\circ} \mathrm{C}$ for $24 \mathrm{~h}$ and used as substrate for anaerobic digestion.

\subsection{VFAs production from wastepaper by $O C F$}

Anaerobic open culture fermentation (OCF) was carried out in $250 \mathrm{~mL}$ reactors (serum bottles with seals) with $100 \mathrm{~mL}$ of anaerobic fermenter medium [modified RAMM medium containing 1; yeast extract, $0.27 ; \mathrm{KH}_{2} \mathrm{PO}_{4}, 0.35 ; \mathrm{K}_{2} \mathrm{HPO}_{4}, 0.53 ; \mathrm{NH}_{4} \mathrm{Cl}, 0.1 ; \mathrm{MgCl} \cdot 6 \mathrm{H}_{2} \mathrm{O}, 0.075$;

$\mathrm{CaCl} 2 \cdot 2 \mathrm{H}_{2} \mathrm{O}$ and $\left.10 ; \mathrm{NaHCO}_{3}\right]$ with the solid loading of $10 \%(\mathrm{w} / \mathrm{v})$ pretreated WOP and WNP. $\mathrm{NaHCO}_{3}$ was added to the medium separately as an alkaline buffer. The trace element solution (DSMZ 320, 0.1\% v/v) and vitamin solution (DSMZ 503, 0.1\% (v/v) was added to the fermentation medium and the $\mathrm{pH}$ was adjusted to $8.0 \quad(2 \mathrm{~N} \mathrm{HCl}$ and $\mathrm{NaOH})$. 2mercaptoethanesulfonate (BES) (12 mM) was used as a methanogens inhibitor. The reactors were seeded with $10 \%(\mathrm{v} / \mathrm{v})$ inoculum, purged with nitrogen gas for $10 \mathrm{~min}$, sealed with rubber stopper with crimp aluminum seals and incubated at $30^{\circ} \mathrm{C}$ with $100 \mathrm{rpm}$ for 4 weeks. After incubation, the broth from OCF was centrifuged (Eppendorf-5810R, Germany) at 10,000 xg for

10 min and the supernatant was subjected to struvite precipitation at $1: 1: 1.1\left(\mathrm{Mg}^{2+}: \mathrm{NH}^{4+}-\mathrm{N}\right.$ : 
$\left.121 \mathrm{PO}_{4}^{3-}-\mathrm{P}\right)$ molar concentration to achieve $\mathrm{C} / \mathrm{N}$ ratio of 40 and subsequently used for lipid 122 production.

125 broth obtained from OCF. No additional nutrients were added. Seed cultures were grown for $24 \mathrm{~h}$

126 in synthetic VFAs media until reaching an Optical Density of 1 at a wavelength of $600 \mathrm{~nm}$

$127\left(\mathrm{OD}_{600}\right)$. Flasks were inoculated with $1 \%(\mathrm{v} / \mathrm{v})$ seed cultures subsequently grown for $72 \mathrm{~h}$ at

$12830{ }^{\circ} \mathrm{C}$ and $200 \mathrm{rpm}$. Aliquots $(5 \mathrm{~mL})$ were withdrawn at regular intervals $(12 \mathrm{~h})$ and used to 129 determine cell biomass, lipid production and residual VFAs in the medium. Biomass was 130 estimated gravimetrically by centrifuging the culture broth $(5 \mathrm{~mL})$ at $5000 \mathrm{xg}$ for $10 \mathrm{~min}$ at $4^{\circ} \mathrm{C}$, 131 washed with deionized water and dried at $60^{\circ} \mathrm{C}$ for $24 \mathrm{~h}$ and expressed as cell dry cell weight $(\mathrm{g}$ $132 \mathrm{DCW} / \mathrm{L})$.

\subsection{Analytical methods}

Total Solids (TS) were determined by drying at $105^{\circ} \mathrm{C}$ overnight and volatile solids (VS) 135 were determined by ashing at $550{ }^{\circ} \mathrm{C}$ for $3 \mathrm{~h}$ [24]. Total nitrogen (TN) and ammonium nitrogen $136\left(\mathrm{NH}_{3}-\mathrm{N}\right)$ were measured using a standard method [24]. The concentrations of VFAs were 137 analyzed using an HPLC (Agilent Technology 1100 series) equipped with Aminex HPX-87H 138 column (BIORAD INC., USA), using refractive index (RI) and diode array detectors (DAD). 139 The mobile phase was $0.004 \mathrm{M} \mathrm{H}_{2} \mathrm{SO}_{4}$ at a flow rate was $0.6 \mathrm{~mL} / \mathrm{min}$ and the column 140 temperature was maintained constant at $50^{\circ} \mathrm{C}$. Samples were filter through $0.2 \mu \mathrm{m}$ (PVDF) 141 syringe filter (Millipore, USA) and subsequently used for analysis. 
Lipids extraction from dried biomass was done by the method of Folch et al. [25]. 143 Briefly, $10 \mathrm{mg}$ of dried biomass was digested using $3.2 \mathrm{~mL}$ of $4 \mathrm{M} \mathrm{HCl}$ at $55^{\circ} \mathrm{C}$ for $2 \mathrm{~h}$ and 144 extracted with $8 \mathrm{~mL}$ of chloroform/methanol (2:1, v/v), vortexed for $2-3 \mathrm{~min}$ and centrifuged at $1452,000 x g$ for $5 \mathrm{~min}$. Further, the extracted solution was purged with nitrogen gas to evaporate the solvents and the lipids were measured and expressed as $\mathrm{g} / \mathrm{L}$. containing (10 mL/L) nonadecanoic acid (C19:0) as an internal standard and heated at $100^{\circ} \mathrm{C}$ for $4 \mathrm{~h}$. After cooling to room temperature, $1 \mathrm{~mL}$ of distilled water was added, vortexed for $3 \mathrm{~min}$ and centrifuged at 2,000 $x \mathrm{~g}$ for $1 \mathrm{~min}$ for organic phase separation. FAMEs were analyzed by GC 151 (Agilent 7890A, USA) equipped with flame ionization detector (FID) and FAMEWAX column $152(30 \mathrm{~m} \times 320 \mu \mathrm{m} \times 0.25 \mu \mathrm{m})$ using helium as a carrier gas. The injector was kept at $280^{\circ} \mathrm{C}$ with an 153 injection volume of $1 \mu \mathrm{L}$ with a split ratio at 30 . The initial oven temperature was set at $120^{\circ} \mathrm{C}$. 154 The oven temperature was increased at a heating rate of $3^{\circ} \mathrm{C} / \mathrm{min}$ up to $240^{\circ} \mathrm{C}$ and held for 20 $155 \min$. The temperature of the detector was set at $250^{\circ} \mathrm{C}$. Fatty acids were calculated relative to 156 their weight compared to total lipids in biomass and expressed as percentage (\% total lipids).

\section{3. Results and discussion}

\subsection{Effect of VFAs concentration and ratio on biomass and lipid production}

The effects of initial concentration of VFAs on biomass and lipid production was 160 investigated and presented in Table 1. Biomass and lipid yield achieved was $1.62 \pm 0.06$ and $0.587 \pm 0.004,2.78 \pm 0.08$ and $0.781 \pm 0.008$, and $4.19 \pm 0.11$ and $0.712 \pm 0.005 \mathrm{~g} / \mathrm{L}$, and lipid

162 content achieved was $36.3 \pm 0.21,28.1 \pm 0.18$ and $17.0 \pm 0.20 \%$ with 2,5 and $10 \mathrm{~g} / \mathrm{L}$ VFAs 163 concentration, respectively. These results evidenced that $C$. curvatus was able to grow even at 
164 10g/L VFAs concentration; however, there was a considerable decrease in lipid production 165 reported with increasing the concentration VFAs, which clearly suggesting that the higher 166 concentration of VFAs promotes the cell growth than lipid accumulation. Thus, the initial 167 concentration of $5 \mathrm{~g} / \mathrm{L}$ VFAs was considered as most suitable resulting in high yield of biomass 168 and lipid production compared to the other tested VFAs concentration. Park et al. [12] reported 169 that the yeast, $C$. curvatus was not able to utilize $8 \mathrm{~g} / \mathrm{L}$ of VFAs; however, lipid production was 170 elevated with increasing VFAs to $6 \mathrm{~g} / \mathrm{L}$. Several other studies also reported that there was a 171 significant inhibition on lipid production when VFAs concentration increased above 5 g/L [26, 172 27].

The effect of different ratio of VFAs on biomass and lipid production was investigated 174 with four different ratios such as 5:1:4, 5:2:3, 6:2:2 and 6:1:3 (AA: BA: PA). The cell biomass 175 and lipid yield achieved was ranged between $3.62 \pm 0.10$ and $4.38 \pm 0.08 \mathrm{~g} / \mathrm{L}$, and $0.85 \pm 0.004$ 176 and $1.69 \pm 0.010 \mathrm{~g} / \mathrm{L}$, respectively (Table.1). The results suggested that maximum biomass (4.38

$177 \pm 0.08 \mathrm{~g} / \mathrm{L})$, lipid production $(1.69 \pm 0.010 \mathrm{~g} / \mathrm{L})$ and lipid yield coefficient $(0.338 \mathrm{~g} / \mathrm{g})$ was 178 achieved with the VFAs ratio of 6:1:3. Our results showed that high content of acetic acid (AA) 179 in VFAs mixture greatly promotes the cell biomass and lipid productivity; hence, acetic acid is 180 more favorable for high productivity than butyric and propionic acids. Liu et al. [28] reported 181 that high content of AA in VFAs mixture (6:3:1) increased the biomass and productivity by $C$. 182 curvatus utilizing WAS- derived VFAs through sequencing batch fermentation strategy.

\subsection{Effect of various nitrogen sources on lipid accumulation}

Several studies suggested that lipid accumulation using VFAs were greatly influenced by nitrogen source used for production. In this study, effect of various nitrogen sources was 
186

187

188

189

190

191

192

193

194

195

196

197

198

199

200

201

202

203

204

205

206

207

208

investigated using synthetic VFAs at $5 \mathrm{~g} / \mathrm{L}$ with $\mathrm{C} / \mathrm{N}$ ratio 40 as presented in Table 2 . The cell biomass achieved from the nitrogen sources such as ammonium sulphate, ammonium chloride, ammonium nitrate, sodium nitrate, potassium nitrate, yeast extract and peptone were $3.60 \pm 0.13$, $3.69 \pm 0.14,3.71 \pm 0.16,1.49 \pm 0.08,1.36 \pm 0.08,3.24 \pm 0.15$ and $4.17 \pm 0.12(\mathrm{~g} / \mathrm{L})$, respectively. The lipid yield (g/L) and lipid content (\%) achieved using ammonium sulphate, ammonium chloride, ammonium nitrate, sodium nitrate, potassium nitrate, yeast extract and peptone were $0.236 \pm 0.006$ and $6.5 \pm 0.18,0.456 \pm 0.008$ and $12.4 \pm 0.08,0.416 \pm 0.006$ and $11.2 \pm 0.12,0.256 \pm 0.005$ and $17.2 \pm 0.14,0.139 \pm 0.004$ and $10.2 \pm 0.08,0.790 \pm 0.006$ and $24.4 \pm 0.16$, and $0.556 \pm 0.008$ and $13.3 \pm 0.10$, respectively. The results of combined addition of organic and inorganic nitrogen (1:1) suggested that maximum cell biomass $(5.53 \pm 0.09 \mathrm{~g} / \mathrm{L})$, lipid yield $(1.724 \pm 0.008 \mathrm{~g} / \mathrm{L})$ and lipid content $(31.2 \pm 0.13)$ was achieved with the combination of ammonium nitrate and yeast extract. These results clearly suggested that the nitrogen sources playing an important role in cell biomass and lipid production, and the combined addition of ammonium nitrate and yeast extract (1:1) was most suitable for high yield of lipids while using VFAs as a carbon source. Several other studies also reported that the combination of both organic and inorganic nitrogen sources were significantly higher than the yield achieved while using organic/inorganic nitrogen alone with carbon sources [7, 29].

\subsection{VFAs production from wastepaper through $O C F$}

The VFAs production profile from WOP and WNP by OCF suggested that VFAs production started at day 2 and reached maximum after 20 days (Fig. 1). VFAs produced from WOP and WNP were $17.28 \pm 0.67$ and $10.23 \pm 0.52 \mathrm{~g} / \mathrm{L}$ with the total nitrogen of $106.16 \pm 2.34$ and $82.62 \pm 1.52 \mathrm{mg} / \mathrm{L}$, respectively. The VFAs yield and productivity achieved from WOP and WNP were $0.173 \mathrm{~g} / \mathrm{g}$ TS and $0.864 \mathrm{~g} / \mathrm{L} / \mathrm{day}$, and $0.102 \mathrm{~g} / \mathrm{g}$ TS and $0.512 \mathrm{~g} / \mathrm{L} /$ day, respectively. 
Sawatdeenarunat et al. [30] (2017) achieved a VFAs yield of $107.25 \pm 2.19 \mathrm{mg} / \mathrm{gVS}$ from anaerobic digestion of Napier grass using micro oxygenation. Park et al. [12] reported that 8.12 $\mathrm{g} / \mathrm{L}$ of VFAs obtained from rice straw after 2 weeks of anaerobic fermentation with $\mathrm{NH}_{3}-\mathrm{N}$ and total-N content of $75.16 \mathrm{mg} / \mathrm{L}$ and $129.33 \mathrm{mg} / \mathrm{L}$, respectively.

Figure 2 shows the composition of VFAs produced from WOP and WNP. Results suggests that acetic, butyric and propionic acids were produced equally at the earlier stages (4 days); however, acetic acid was remained as most dominated thereafter followed by propionic and butyric acid. The composition of VFAs was 53.4 and $48.6 \%$ AA, 35.6 and $35.8 \%$ PA, and 11.0 and $17.3 \%$ BA with WOP and WNP, respectively. Our results are consistent compared to previous studies where a similar trend was observed with the dominance of acetic, propionic, and butyric acids during anaerobic digestion of various waste biomasses [12, 30].

\subsection{Lipid production utilizing VFAs produced from wastepaper}

Lipid production using the VFAs derived from anaerobic OCF of WOP and WNP was carried out by growing the oleaginous yeast, C. curvatus for $72 \mathrm{~h}$ at $30^{\circ} \mathrm{C}$ without any additional nutrients at a $\mathrm{C} / \mathrm{N}$ ratio of 40 . During the batch cultivation, cell biomass production was increased constantly from the beginning and reached maximum at 48 and $24 \mathrm{~h}$ with WOP and WNP, respectively (Fig.3 a \& b). Lipid accumulation was also increased with time and reached maximum at $48 \mathrm{~h}$ without any further increase. Biomass, lipid yield and lipid content achieved from the VFAs of WOP and WNP were $4.32 \pm 0.24$ and $2.91 \pm 0.23 \mathrm{~g} / \mathrm{L}, 1.78 \pm 0.12$ and $0.80 \pm$ $0.06 \mathrm{~g} / \mathrm{L}$, and $41.2 \pm 0.62$ and $27.7 \pm 0.36 \%$, respectively (Table 3 ). The lipid coefficient achieved was $0.11 \pm 0.02$ and $0.08 \pm 0.02 \mathrm{~g} / \mathrm{g}$ VFA with the productivity of $0.037 \pm 0.004$ and $0.033 \pm 0.006 \mathrm{~g} / \mathrm{L} / \mathrm{h}$ from VFAs of WOP and WNP, respectively. The results suggested that the 
231 cell biomass and lipid yield achieved from VFAs of WOP was comparatively higher than the

232 VFAs of WNP, due to the high yield of VFAs and compositional variation between WOP and

233 WNP. Xu et al. [4] achieved $2.5 \mathrm{~g} / \mathrm{L}$ biomass with lipid productivity of $0.272 \mathrm{~g} / \mathrm{L} / \mathrm{d}$ from $C$.

234 curvatus utilizing VFAs from anaerobic digestion of macroalgae.

The results of VFAs consumption during batch cultivation suggested that all of the three VFAs were started to be utilized from the beginning of fermentation, and were completely 237 exhausted within 72 and $60 \mathrm{~h}$ with the VFAs of WOP and WNP, respectively (Fig. 4). The 238 results suggested that acetic acid was mainly utilized up to $36 \mathrm{~h}$ followed by butyric and 239 propionic acids. Though biomass and lipid production were increased with decreasing VFAs 240 concentration in the medium, rate of production was comparatively high during assimilation of 241 acetic acid than other VFAs. Previous studies also suggested that high proportion of acetic acid 242 was more advantageous for the synthesis of microbial lipids and cell mass production than 243 butyric and propionic acids [31, 32]. These results also indicated that $C$. curvatus is able to 244 utilize all three kinds of acid simultaneously, but preferably acetic acid than propionic and 245 butyric acids due to the variation in metabolic fate of each single VFAs [17, 33]. Acetic acid can 246 be directly transformed to acetyl-coenzyme A (CoA), which can be used to synthesize microbial 247 oils. Contrarily, propionate, an odd-chain carboxylic acid, is converted to propionyl CoA and 248 then enters the tricarboxylic acid (TCA) cycle via methylmalonyl-CoA interconversion to 249 succinyl-CoA. On the other hand, butyrate undergoes $\beta$-oxidation to produce acetoacetyl-CoA 250 which is further transformed into acetyl-CoA $[17,33]$. 
Fatty acid profile analysis of the lipids produced by $C$. curvatus suggested that $\mathrm{C} 18$ fatty 253 acids (stearic, oleic, linoleic acid) were dominated (80\%), followed by C16 fatty acid (palmitic 254 acid) (15\%). The results suggested that the oleic acid (52.64 \pm 1.32 and $50.65 \pm 1.82 \%)$ was the 255 most abundant fatty acid followed by palmitic acid (16.42 \pm 1.16 and $15.18 \pm 0.82 \%)$, stearic 256 acid $(15.26 \pm 0.78$ and $14.41 \pm 0.69 \%)$ and linoleic acid $(12.25 \pm 0.82$ and $12.16 \pm 0.71 \%)$ in

257 lipids produced from VFAs of WOP and WNP, respectively. Several other studies were also 258 reported that palmitic acid, stearic acid, and oleic acid were the major fatty acids of lipids 259 produced by $C$. curvatus using VFAs derived from various sources $[4,12]$. Thus, the long chain 260 saturated and unsaturated fatty acids (C16 and C18) are the main components of the lipid, which 261 is similar to the typical plant/vegetable oils, suggesting its potential to use as a feedstock for 262 large scale production of biodiesel.

\section{Conclusions}

Utilization of wastepaper for production of microbial lipids to use as feedstock for

265 biodiesel aims to open new avenues for cost-effective production of biofuels through biorefinery 266 concept. Moreover, this biorefinery approach offers a potential valuable and alternative route for 267 management of wastepaper. Importantly, VFAs derived from wastepaper were used for lipid 268 production without the need to supply any additional nutrients. Biomass (4.3 g DCW/L) and lipid 269 accumulation (41\%) achieved in this study was comparatively higher than other studies utilizing 270 VFAs from various sources. Fatty acid profiles of lipids produced were comparable to 271 plant/vegetable oils used for biodiesel production, and hence, VFAs derived from wastepaper 272 could be a potential feedstock for microbial lipids production to use as non-edible lipid source 273 for biodiesel. However, further investigations will be needed to ensure process scale up 274 feasibility and sustainable production. 


\section{References}

[1] Cao X. Climate change and energy development: implications for developing countries. Resour Policy 2003; 29: 61-67. https://doi.org/10.1016/j.resourpol.2004.05.001.

[2] Chauhan SK, Shukla A. Environmental impacts of production of biodiesel and its use in transportation sector. In: Environmental Impact of Biofuels. InTech; 2011, p.1-18.

[3] Subramaniam R, Dufreche S, Zappi M, Bajpai R. Microbial lipids from renewable resources: production and characterization. J Ind Microbiol Biotechnol 2010; 37(12):1271-1287. https://doi.org/10.1007/s10295-010-0884-5.

[4] Xu X, Kim JY, Cho HU, Park HR, Park JM. Bioconversion of volatile fatty acids from macroalgae fermentation into microbial lipids by oleaginous yeast. Chem Eng J 2015; 264: 735-743. https://doi.org/10.1016/j.cej.2014.12.011.

[5] Meng X, Yang J, Xu X, Zhang L, Nie Q, Xian M. Biodiesel production from oleaginous $\begin{array}{lllll}\text { microorganisms. } & \text { Renew } & \text { Energy } & \text { 2009; }\end{array}$ https://doi.org/10.1016/j.renene.2008.04.014.

[6] Leiva- Candia DE, Pinzi S, Redel-Macias MD, Koutinas A, Webb C, Dorado MP. The potential for agro-industrial waste utilization using oleaginous yeast for the production of biodiesel. Fuel 2014; 123: 33-42. https://doi.org/10.1016/j.fuel.2014.01.054.

[7] Annamalai N, Sivakumar N, Oleskowicz - Popiel P. Enhanced production of microbial lipids from waste office paper by the oleaginous yeast Cryptococcus curvatus. Fuel 2018; 217: 420-426. https://doi.org/10.1016/j.fuel.2017.12.108. 
295 [8] Ananthi V, Siva Prakash G, Chang SW, Ravindran B, Nguyen DD, Vo DVN, La DD, Bach

296

297

298

299

300

301

302

303

304

305

306

307

308

309

310

311

312

313

314

315

QV, Wong JWC, Gupta SK, Selvaraj A, Arun A. Enhanced microbial biodiesel production from lignocellulosic hydrolysates using yeast isolates. Fuel 2019; 256:115932. https://doi.org/10.1016/j.fuel.2019.115932.

[9] Fei Q, Chang HN, Shang L, Choi J d-r. Exploring low-cost carbon sources for microbial lipids production by fed-batch cultivation of Cryptococcus albidus. Biotechnol Bioprocess Eng 2011a; 16: 482-487. https://doi.org/10.1007/s12257-010-0370-y.

[10] Vajpeyi S, Chandran K. Microbial conversion of synthetic and food waste-derived volatile fatty acids to lipids. Bioresour Technol 2015; 188: 49-55. https://doi.org/10.1016/j.biortech.2015.01.099.

[11] Ahmad FB, Zhang Z, Doherty WOS, Teo VSJ, Hara IMO. Improved microbial oil production from oil palm empty fruit bunch by Mucor plumbeus. Fuel 2017; 194: 180187. https://doi.org/10.1016/j.fuel.2017.01.013.

[12] Park GW, Chang HN, Jung K, Seo C, Kim YC, Choi JH, Woo HC, Hwang I. Production of microbial lipid by Cryptococcus curvatus on rice straw hydrolysates. Process Biochem 2017; 56: 147-53. https://doi.org/10.1016/j.procbio.2017.02.020.

[13] Hii K, Baroutian S, Parthasarathy R, Gapes DJ, Eshtiaghi N. A review of wet air oxidation and thermal hydrolysis technologies in sludge treatment. Bioresour Technol 2014; 155 : 289-299. https://doi.org/10.1016/j.biortech.2013.12.066.

[14] Cho HU, Kim YM, Choi YN, Xu X, Shin DY, Park JM. Effects of pH control and concentration on microbial oil production from Chlorella vulgaris cultivated in the 
effluent of a low-cost organic waste fermentation system producing volatile fatty acids. Bioresour Technol 2015; 184: 245-250. https://doi.org/10.1016/j.biortech.2014.09.069.

[15] Jankowska E, Chwiałkowska J, Stodolny M, Oleskowicz-Popiel P. Effect of pH and retention time on volatile fatty acids production during mixed culture fermentation. Bioresour Technol 2015; 190: 274-280. https://doi.org/10.1016/j.biortech.2015.04.096.

[16] Lian J, Garcia-Perez M, Coates R, Wu H, Chen S. Yeast fermentation of carboxylic acids obtained from pyrolytic aqueous phases for lipid production. Bioresour Technol 2012; 118: 177-186. https://doi.org/10.1016/j.biortech.2012.05.010.

[17] Zheng Y, Chi Z, Ahring BK, Chen S. Oleaginous yeast Cryptococcus curvatus for biofuel production: ammonia's effect. Biomass Bioenerg 2012; 37: 114-121. https://doi.org/10.1016/j.biombioe.2011.12.022.

[18] Ruan ZH, Zanotti M, Zhong Y, Liao W, Ducey C, Liu Y. Co-hydrolysis of lignocellulosic biomass for microbial lipid accumulation. Biotechnol Bioeng 2013; 110: 1039-1049. https://doi.org/10.1002/bit.24773.

[19] Harde SM, Wang Z, Horne M, Zhu JY, Pan X. Microbial lipid production from SPORLpretreated Douglas fir by Mortierella isabellina. Fuel 2016; 175: 64-74. https://doi.org/10.1016/j.fuel.2016.02.023.

[20] Annamalai N, Al Battashi H, Nair AS, Al Azkawi A, Al Bahry S, Sivakumar N. Enhanced bioethanol production from waste paper through separate hydrolysis and fermentation. Waste Biomass Valori 2020; 11: 121-131. https://doi.org/10.1007/s12649-018-0400-0. 
[21] Huang C, Chen XF, Xiong L, Chen XD, Ma LL, Chen Y. Single cell oil production from low-cost substrates: the possibility and potential of its industrialization. Biotechnol Adv 2013; 31:129-139. https://doi.org/10.1016/j.biotechadv.2012.08.010.

[22] Nishimura H, Tan L, Sun ZY, Tang YQ, Kida K, Morimura S. Efficient production of ethanol from waste paper and the biochemical methane potential of stillage eluted from ethanol fermentation. Waste Manage 2016; 48(8): 644-651. https://doi.org/10.1016/j.wasman.2015.11.051.

[23] Wang L, Sharifzadeh M, Templer R, Murphy RJ. Bioethanol production from various waste papers: Economic feasibility and sensitivity analysis. Appl Energ 2013; 111: 1172-1182. https://doi.org/10.1016/j.apenergy.2012.08.048.

[24] APHA. Standard methods for the examination of water and wastewater, $20^{\text {th }}$ ed. American Public Health Association, Washington: DC, USA; 2008.

[25] Folch J, Lees M, Sloane-Stanley GH. A simple method for the isolation and purification of total lipids from animal tissues. J Biol Chem 1957; 226: 497-509.

[26] Fei Q, Chang HN, Shang LA, Choi JDR, Kim N, Kang J. The effect of volatile fatty acids as a sole carbon source on lipid accumulation by Cryptococcus albidus for biodiesel production. Bioresour Technol 2011b; 102: 2695-2701. https://doi.org/10.1016/j.biortech.2010.10.141.

[27] Yahara GA, Javier MA, Tulio MJM, Javier GR. Modeling of yeast Brettanomyces bruxellensis growth at different acetic acid concentrations under aerobic and anaerobic 
conditions. Bioprocess Biosys Eng 2007; 30: 389-395. https://doi.org/10.1007/s00449007-0135-y.

[28] Liu J, Yuan M, Liu JN, Lu LJ, Peng KM, Huang XF. Microbial conversion of mixed volatile fatty acids into microbial lipids by sequencing batch culture strategy. Bioresour Technol 2016; 222: 75-81. https://doi.org/10.1016/j.biortech.2016.09.100.

[29] Chang HN, Kim NJ, Kang JW, Jeong CM. Biomass-derived volatile fatty acid platform for fuels and chemicals. Biotechnol Bioprocess Eng 2010; 15: 1-10. https://doi.org/10.1007/s12257-009-3070-8.

[30] Sawatdeenarunat C, Sung S, Khanal SK. Enhanced volatile fatty acids production during anaerobic digestion of lignocellulosic biomass via micro-oxygenation. Bioresour Technol 2017; 237: 139-145. https://doi.org/10.1016/j.biortech.2017.02.029.

[31] Fontanille P, Kumar V, Christophe G, Nouaille R, Larroche C. Bioconversion of volatile fatty acids into lipids by the oleaginous yeast Yarrowia lipolytica. Bioresour Technol 2012; 114: 443-449. https://doi.org/10.1016/j.biortech.2012.02.091.

[32] Kolouchova I, Schreiberova O, Sigler K, Masak J, Rezanka T. Biotransformation of volatile fatty acids by oleaginous and non-oleaginous yeast species. FEMS Yeast Res 2015; 15: 76-84. https://doi.org/10.1093/femsyr/fov076.

[33] Fradinho JC, Oehmen A, Reis MAM. Photosynthetic mixed culture polyhydroxyalkanoate (PHA) production from individual and mixed volatile fatty acids (VFAs): substrate preferences and co-substrate uptake. J Biotechnol 2014; 185: 19-27. https://doi.org/10.1016/j.jbiotec.2014.05.035. 
378 


\section{Production of microbial lipids utilizing volatile fatty acids derived from wastepaper: A} biorefinery approach for biodiesel production

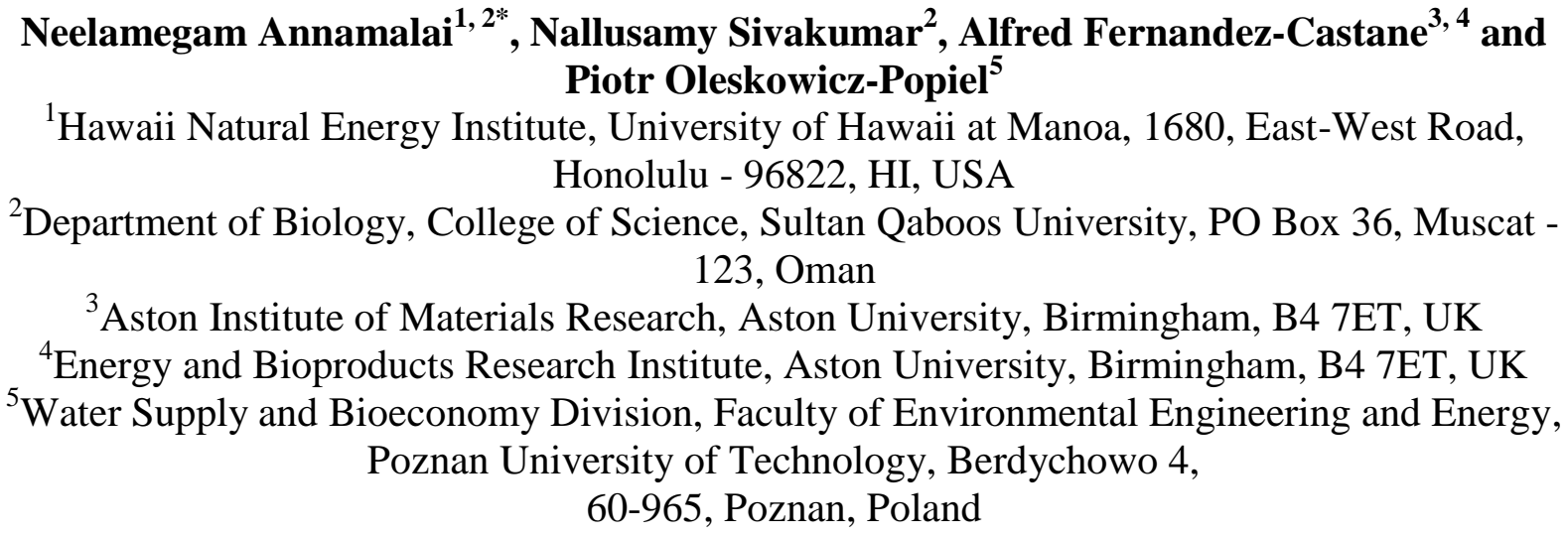

\section{Abstract}

Volatile fatty acids (VFAs) derived from organic wastes are being considered as low-cost feedstock for microbial lipid production as a valuable alternative to plant derived oils/biodiesel. In this study, VFAs were produced from anaerobic open culture fermentation of wastepaper and subsequently, used as feedstock for lipid production by Cryptococcus curvatus. Total VFAs, yield and productivity achieved from waste office paper (WOP) and newspaper (WNP) were 17.3 and $10.2 \mathrm{~g} / \mathrm{L}, 0.17$ and $0.10 \mathrm{~g} / \mathrm{g}$ TS, and 0.86 and $0.51 \mathrm{~g} / \mathrm{L} / \mathrm{day}$, respectively. Biomass, lipid content and productivity achieved utilizing VFAs of WOP and WNP were 4.3 and $2.9 \mathrm{~g} / \mathrm{L}, 41.2$ and $27.7 \% \mathrm{DCW}$, and 0.037 and $0.033 \mathrm{~g} / \mathrm{L} / \mathrm{h}$, respectively. The dominance of fatty acids such as oleic, palmitic, stearic and linoleic acid in the lipids suggests a high level of similarity with plant/vegetable oils used for biodiesel production. Therefore, VFAs derived from wastepaper could be potentially used as feedstock to produce microbial lipids towards cost-effective production of biodiesel.

Keywords: Biodiesel; Volatile fatty acids; Wastepaper; Anaerobic open culture fermentation; Oleaginous yeast; Microbial lipids.

*Corresponding Authors: Neelamegam Annamalai, Email: annabact@gmail.com, Tel.: +1 8086836910 


\section{Introduction}

Currently, the world is facing global challenges such as fossil fuel depletion and climate change caused by global warming due to the increase of greenhouse gasses (GHGs) emissions

34 from fossil fuels $[1,2]$. Biodiesel, fatty acids alkyl ester, can be obtained by transesterification of triacylglycerol from edible vegetable oils (i.e. soybean, sunflower and palm oil), fats and cooling oil wastes, has several advantages than conventional petroleum-based diesel fuel such as non-

37 sulfur oxide emission, sustainability and potential for carbon reduction [3]. However, the use of these edible oils as a feedstock for biodiesel limiting its commercialization as it competes with food production and increase the cost of raw material such as vegetables and agricultural commodities [4]. Microbial lipids produced by oleaginous microorganisms, which accumulates $20-80 \%$ of their dry weight in the form of lipids under nutrient-limitation conditions, are the most promising alternative non-edible lipid source for sustainable production of biodiesel [5-8].

43 However, the production cost of microbial lipids remains as a major limiting factor due to the 44 carbon sources used for production, which is estimated to be about $80 \%$ of the total medium cost and it contributes to over $60 \%$ of the total production costs while using glucose as a carbon

46 source [9]. A potential solution to reduce the production cost is to utilize low-cost or waste

47 biomass that can be used as a substrate for microbial lipid production $[8,10,11]$.

Volatile fatty acids (VFAs) are linear short-chain fatty acids (C2 - C5), which includes 49 acetic, propionic, butyric, isobutyric, valeric, isovaleric and 2-methylbutyric acid are 50 intermediate products of anaerobic digestion (AD), have been extensively investigated for 51 production of various bio-based materials, using a so-called VFAs platform [12-14]. The major 52 advantages of VFAs platform for bio-based materials production are the absence of requirement 53 for sterilization or addition of enzymes to hydrolyze, and the availability of feedstock in 
54 substantial quantities [15].VFAs are considered as a potential carbon source for lipid production

55 using oleaginous yeast as it requires only shorter transformation pathway (VFAs into acetyl-

56 CoA, which is used for biosynthesis of lipids) with high theoretical lipid conversion efficiency

$57[16,17]$.

Microbial lipids production utilizing lignocellulosic biomass has received increasing 59 interest in recent days, as an alternative solution for large-scale production of biodiesel [7, 18, 19]. Wastepaper, a major component of municipal and industrial solid wastes, accounts more

61 than $35 \%$ of total lignocellulosic wastes is being considered as a promising feedstock for biofuels

62 due to its sustainability and abundance [20,21]. Recently, wastepaper has been used as feedstock

63 for production of various valuable bio-products such as bioethanol and PHAs [7, 20, 22].

64 Utilization of wastepaper for production of microbial lipids is a promising alternative biorefinery

65 approach for large-scale production of biodiesel, which is not only reduces the cost of 66 production, but also provides alternative route for waste management [23]. Hence, in this study 67 we aim to investigate the conversion of wastepaper into VFAs through anaerobic open culture 68 fermentation (OCF) and subsequently, use the VFAs as possible feedstock for production of 69 microbial lipids as an alternative to industrial production of biodiesel.

\section{2. Materials and methods}

All chemicals and reagents used in this study were purchased from Sigma-Aldrich (St.

72 Louis, MO, USA) or as indicated.

\section{2.1. Inocula}

74 2.1.1. Inoculum for VFAs production

Waste activated sludge (WAS) obtained from local wastewater treatment plant was 76 passed through a sieve ( $18 \mathrm{mesh})$ and heat treated at $90^{\circ} \mathrm{C}$ for $20 \mathrm{~min}$ to inactivate methanogens. 
77 The raw sludge contained $1.59 \pm 0.01 \mathrm{~g} / \mathrm{L}$ total suspended solid (TSS) and $1.36 \pm 0.01 \mathrm{~g} / \mathrm{L}$

78 volatile suspended solid (VSS). Further, WAS purged with $\mathrm{N}_{2}$ gas for $10 \mathrm{~min}, \mathrm{pH}$ maintained at

$795.4-5.6$ using $2 \mathrm{~N} \mathrm{HCl}$ and $\mathrm{NaOH}$, incubated in a shaker incubator at $35^{\circ} \mathrm{C}$ and $200 \mathrm{rpm}$ was

80 used as a inoculum for VFA production.

81

82

83

84

85

86

87

88

\subsubsection{Inoculum for microbial lipid production}

The oleaginous yeast, Cryptococcus curvatus DSM 70022 obtained from DSMZ (Germany) was propagated on YPD agar slants in every two weeks (yeast extract 10; peptone 10; glucose 20; agar 15 (g/L), pH 6.0, 30 $\mathrm{C}$ ). For seed culture, C. curvatus was inoculated into 50 $\mathrm{mL}$ of YPD medium in $250 \mathrm{~mL}$ flask and incubated at $30^{\circ} \mathrm{C}, 200 \mathrm{rpm}$ for $36 \mathrm{~h}$. Afterwards, the cultures were grown in a medium containing $10 \mathrm{~g} / \mathrm{L}$ acetate, $2 \mathrm{~g} / \mathrm{L}$ propionate, $1 \mathrm{~g} / \mathrm{L}$ butyrate, 1 $\mathrm{g} / \mathrm{L}$ peptone, and $1 \mathrm{~g} / \mathrm{L}$ yeast extract $(\mathrm{pH}-5.5)$ for $24 \mathrm{~h}$ and used as a inoculum for lipid production.

\subsection{Feasibility of C. curvatus for lipid production using VFAs}

The feasibility of C. curavtus for lipid production using VFAs was investigated using synthetic VFAs [mixture of acetic acid (AA), propionic acid (PA) and butyric acid (BA)]. The influence of VFAs on lipid accumulation was studied by comparing the initial concentration and ratio of each VFA in the mixture. The effect of initial VFAs concentration was evaluated using 2, 5 and $10 \mathrm{~g} / \mathrm{L}$ at a ratio of 5:1:4. Effects of various VFAs ratio (AA: BA: PA) (5:1:4, 5:2:3, 6:2:2 and 6:1:3) on lipid accumulation was investigated at an initial concentration of $5 \mathrm{~g} / \mathrm{L}$ VFAs. The effect of various nitrogen sources and their combination (1:1) on lipid production was investigated using various inorganic $\left[\left(\mathrm{NH}_{4}\right)_{2} \mathrm{SO}_{4}, \mathrm{NH}_{4} \mathrm{Cl}, \mathrm{NH}_{4} \mathrm{NO}_{3}, \mathrm{NaNO}_{3}\right.$ and $\left.\mathrm{KNO}_{3}\right]$ and organic nitrogen sources [yeast extract $(10 \% \mathrm{~N}, \mathrm{w} / \mathrm{w})$ ] and peptone $(14 \% \mathrm{~N}, \mathrm{w} / \mathrm{w})$ ]. The initial 
$99 \mathrm{pH}$ of the medium was adjusted to 5.5 using $2 \mathrm{~N} \mathrm{HCl}$ and $\mathrm{NaOH}$, and the $\mathrm{C} / \mathrm{N}$ ratio was 100 maintained at 40 under all tested concentrations.

101

102

103

104

105

106

107

108

109

110

111

112

113

114

115

116

117

118

119

120

\subsection{Feedstock pretreatment for VFAs production}

The feedstock for VFAs production such as waste office paper (WOP) and waste newspaper (WNP) were shredded into a small pieces $(2 \times 6 \mathrm{~mm})$ and subjected to pretreatment by mixing with $0.5 \% \mathrm{H}_{2} \mathrm{O}_{2}(5 \% \mathrm{w} / \mathrm{v})$ and then autoclave at $121^{\circ} \mathrm{C}$ for $30 \mathrm{~min}$. The solid residue was collected by centrifugation (Eppendorf-5810R, Germany) at $5000 x g$ for $10 \mathrm{~min}$, washed 3 4 times repeatedly with deionized water until obtain neutral $\mathrm{pH}$, dried at $60^{\circ} \mathrm{C}$ for $24 \mathrm{~h}$ and used as substrate for anaerobic digestion.

\subsection{VFAs production from wastepaper by $O C F$}

Anaerobic open culture fermentation (OCF) was carried out in $250 \mathrm{~mL}$ reactors (serum bottles with seals) with $100 \mathrm{~mL}$ of anaerobic fermenter medium [modified RAMM medium containing 1; yeast extract, $0.27 ; \mathrm{KH}_{2} \mathrm{PO}_{4}, 0.35 ; \mathrm{K}_{2} \mathrm{HPO}_{4}, 0.53 ; \mathrm{NH}_{4} \mathrm{Cl}, 0.1 ; \mathrm{MgCl} \cdot 6 \mathrm{H}_{2} \mathrm{O}, 0.075$;

$\mathrm{CaCl} 2 \cdot 2 \mathrm{H}_{2} \mathrm{O}$ and $\left.10 ; \mathrm{NaHCO}_{3}\right]$ with the solid loading of $10 \%(\mathrm{w} / \mathrm{v})$ pretreated WOP and WNP. $\mathrm{NaHCO}_{3}$ was added to the medium separately as an alkaline buffer. The trace element solution (DSMZ 320, 0.1\% v/v) and vitamin solution (DSMZ 503, 0.1\% (v/v) was added to the fermentation medium and the $\mathrm{pH}$ was adjusted to $8.0 \quad(2 \mathrm{~N} \mathrm{HCl}$ and $\mathrm{NaOH})$. 2mercaptoethanesulfonate (BES) (12 mM) was used as a methanogens inhibitor. The reactors were seeded with $10 \%(\mathrm{v} / \mathrm{v})$ inoculum, purged with nitrogen gas for $10 \mathrm{~min}$, sealed with rubber stopper with crimp aluminum seals and incubated at $30^{\circ} \mathrm{C}$ with $100 \mathrm{rpm}$ for 4 weeks. After incubation, the broth from OCF was centrifuged (Eppendorf-5810R, Germany) at 10,000 xg for

10 min and the supernatant was subjected to struvite precipitation at $1: 1: 1.1\left(\mathrm{Mg}^{2+}: \mathrm{NH}^{4+}-\mathrm{N}\right.$ : 
$\left.121 \mathrm{PO}_{4}^{3-}-\mathrm{P}\right)$ molar concentration to achieve $\mathrm{C} / \mathrm{N}$ ratio of 40 and subsequently used for lipid 122 production.

125 broth obtained from OCF. No additional nutrients were added. Seed cultures were grown for $24 \mathrm{~h}$

126 in synthetic VFAs media until reaching an Optical Density of 1 at a wavelength of $600 \mathrm{~nm}$

$127\left(\mathrm{OD}_{600}\right)$. Flasks were inoculated with $1 \%(\mathrm{v} / \mathrm{v})$ seed cultures subsequently grown for $72 \mathrm{~h}$ at

$12830{ }^{\circ} \mathrm{C}$ and $200 \mathrm{rpm}$. Aliquots $(5 \mathrm{~mL})$ were withdrawn at regular intervals $(12 \mathrm{~h})$ and used to 129 determine cell biomass, lipid production and residual VFAs in the medium. Biomass was 130 estimated gravimetrically by centrifuging the culture broth $(5 \mathrm{~mL})$ at $5000 \mathrm{xg}$ for $10 \mathrm{~min}$ at $4^{\circ} \mathrm{C}$, 131 washed with deionized water and dried at $60^{\circ} \mathrm{C}$ for $24 \mathrm{~h}$ and expressed as cell dry cell weight $(\mathrm{g}$ $132 \mathrm{DCW} / \mathrm{L})$.

\subsection{Analytical methods}

Total Solids (TS) were determined by drying at $105^{\circ} \mathrm{C}$ overnight and volatile solids (VS) 135 were determined by ashing at $550{ }^{\circ} \mathrm{C}$ for $3 \mathrm{~h}$ [24]. Total nitrogen (TN) and ammonium nitrogen $136\left(\mathrm{NH}_{3}-\mathrm{N}\right)$ were measured using a standard method [24]. The concentrations of VFAs were 137 analyzed using an HPLC (Agilent Technology 1100 series) equipped with Aminex HPX-87H 138 column (BIORAD INC., USA), using refractive index (RI) and diode array detectors (DAD). 139 The mobile phase was $0.004 \mathrm{M} \mathrm{H}_{2} \mathrm{SO}_{4}$ at a flow rate was $0.6 \mathrm{~mL} / \mathrm{min}$ and the column 140 temperature was maintained constant at $50^{\circ} \mathrm{C}$. Samples were filter through $0.2 \mu \mathrm{m}$ (PVDF) 141 syringe filter (Millipore, USA) and subsequently used for analysis. 
Lipids extraction from dried biomass was done by the method of Folch et al. [25]. 143 Briefly, $10 \mathrm{mg}$ of dried biomass was digested using $3.2 \mathrm{~mL}$ of $4 \mathrm{M} \mathrm{HCl}$ at $55^{\circ} \mathrm{C}$ for $2 \mathrm{~h}$ and 144 extracted with $8 \mathrm{~mL}$ of chloroform/methanol (2:1, v/v), vortexed for $2-3 \mathrm{~min}$ and centrifuged at $1452,000 x g$ for $5 \mathrm{~min}$. Further, the extracted solution was purged with nitrogen gas to evaporate the solvents and the lipids were measured and expressed as $\mathrm{g} / \mathrm{L}$. containing $(10 \mathrm{~mL} / \mathrm{L})$ nonadecanoic acid $(\mathrm{C} 19: 0)$ as an internal standard and heated at $100^{\circ} \mathrm{C}$ for $4 \mathrm{~h}$. After cooling to room temperature, $1 \mathrm{~mL}$ of distilled water was added, vortexed for $3 \mathrm{~min}$ and centrifuged at 2,000 $x \mathrm{~g}$ for $1 \mathrm{~min}$ for organic phase separation. FAMEs were analyzed by GC 151 (Agilent 7890A, USA) equipped with flame ionization detector (FID) and FAMEWAX column $152(30 \mathrm{~m} \times 320 \mu \mathrm{m} \times 0.25 \mu \mathrm{m})$ using helium as a carrier gas. The injector was kept at $280^{\circ} \mathrm{C}$ with an 153 injection volume of $1 \mu \mathrm{L}$ with a split ratio at 30 . The initial oven temperature was set at $120^{\circ} \mathrm{C}$. 154 The oven temperature was increased at a heating rate of $3^{\circ} \mathrm{C} / \mathrm{min}$ up to $240^{\circ} \mathrm{C}$ and held for 20 $155 \min$. The temperature of the detector was set at $250^{\circ} \mathrm{C}$. Fatty acids were calculated relative to 156 their weight compared to total lipids in biomass and expressed as percentage (\% total lipids).

\section{3. Results and discussion}

\subsection{Effect of VFAs concentration and ratio on biomass and lipid production}

The effects of initial concentration of VFAs on biomass and lipid production was 160 investigated and presented in Table 1. Biomass and lipid yield achieved was $1.62 \pm 0.06$ and 
164 10g/L VFAs concentration; however, there was a considerable decrease in lipid production 165 reported with increasing the concentration VFAs, which clearly suggesting that the higher 166 concentration of VFAs promotes the cell growth than lipid accumulation. Thus, the initial 167 concentration of $5 \mathrm{~g} / \mathrm{L}$ VFAs was considered as most suitable resulting in high yield of biomass 168 and lipid production compared to the other tested VFAs concentration. Park et al. [12] reported 169 that the yeast, $C$. curvatus was not able to utilize $8 \mathrm{~g} / \mathrm{L}$ of VFAs; however, lipid production was 170 elevated with increasing VFAs to $6 \mathrm{~g} / \mathrm{L}$. Several other studies also reported that there was a 171 significant inhibition on lipid production when VFAs concentration increased above $5 \mathrm{~g} / \mathrm{L}$ [26, 172 27].

The effect of different ratio of VFAs on biomass and lipid production was investigated 174 with four different ratios such as 5:1:4, 5:2:3, 6:2:2 and 6:1:3 (AA: BA: PA). The cell biomass 175 and lipid yield achieved was ranged between $3.62 \pm 0.10$ and $4.38 \pm 0.08 \mathrm{~g} / \mathrm{L}$, and $0.85 \pm 0.004$ 176 and $1.69 \pm 0.010 \mathrm{~g} / \mathrm{L}$, respectively (Table.1). The results suggested that maximum biomass (4.38 $177 \pm 0.08 \mathrm{~g} / \mathrm{L})$, lipid production $(1.69 \pm 0.010 \mathrm{~g} / \mathrm{L})$ and lipid yield coefficient $(0.338 \mathrm{~g} / \mathrm{g})$ was 178 achieved with the VFAs ratio of 6:1:3. Our results showed that high content of acetic acid (AA) 179 in VFAs mixture greatly promotes the cell biomass and lipid productivity; hence, acetic acid is 180 more favorable for high productivity than butyric and propionic acids. Liu et al. [28] reported 181 that high content of AA in VFAs mixture (6:3:1) increased the biomass and productivity by $C$. 182 curvatus utilizing WAS- derived VFAs through sequencing batch fermentation strategy.

\subsection{Effect of various nitrogen sources on lipid accumulation}

Several studies suggested that lipid accumulation using VFAs were greatly influenced by 
investigated using synthetic VFAs at $5 \mathrm{~g} / \mathrm{L}$ with $\mathrm{C} / \mathrm{N}$ ratio of 40 as presented in Table 2 . The cell biomass achieved from the nitrogen sources such as ammonium sulphate, ammonium chloride, ammonium nitrate, sodium nitrate, potassium nitrate, yeast extract and peptone were $3.60 \pm 0.13$, $3.69 \pm 0.14,3.71 \pm 0.16,1.49 \pm 0.08,1.36 \pm 0.08,3.24 \pm 0.15$ and $4.17 \pm 0.12(\mathrm{~g} / \mathrm{L})$, respectively. The lipid yield (g/L) and lipid content (\%) achieved using ammonium sulphate, ammonium chloride, ammonium nitrate, sodium nitrate, potassium nitrate, yeast extract and peptone were $0.236 \pm 0.006$ and $6.5 \pm 0.18,0.456 \pm 0.008$ and $12.4 \pm 0.08,0.416 \pm 0.006$ and $11.2 \pm 0.12,0.256 \pm 0.005$ and $17.2 \pm 0.14,0.139 \pm 0.004$ and $10.2 \pm 0.08,0.790 \pm 0.006$ and $24.4 \pm 0.16$, and $0.556 \pm 0.008$ and $13.3 \pm 0.10$, respectively. The results of combined addition of organic and inorganic nitrogen (1:1) suggested that maximum cell biomass $(5.53 \pm 0.09 \mathrm{~g} / \mathrm{L})$, lipid yield $(1.724 \pm 0.008 \mathrm{~g} / \mathrm{L})$ and lipid content $(31.2 \pm 0.13)$ was achieved with the combination of ammonium nitrate and yeast extract. These results clearly suggested that the nitrogen sources playing an important role in cell biomass and lipid production, and the combined addition of ammonium nitrate and yeast extract (1:1) was most suitable for high yield of lipids while using VFAs as a carbon source. Several other studies also reported that the combination of both organic and inorganic nitrogen sources were significantly higher than the yield achieved while using organic/inorganic nitrogen alone with carbon sources [7, 29].

\subsection{VFAs production from wastepaper through $O C F$}

The VFAs production profile from WOP and WNP by OCF suggested that VFAs production started at day 2 and reached maximum after 20 days (Fig. 1). VFAs produced from WOP and WNP were $17.28 \pm 0.67$ and $10.23 \pm 0.52 \mathrm{~g} / \mathrm{L}$ with the total nitrogen of $106.16 \pm 2.34$ and $82.62 \pm 1.52 \mathrm{mg} / \mathrm{L}$, respectively. The VFAs yield and productivity achieved from WOP and WNP were $0.173 \mathrm{~g} / \mathrm{g}$ TS and $0.864 \mathrm{~g} / \mathrm{L} /$ day, and $0.102 \mathrm{~g} / \mathrm{g}$ TS and $0.512 \mathrm{~g} / \mathrm{L} /$ day, respectively. 
Sawatdeenarunat et al. [30] (2017) achieved a VFAs yield of $107.25 \pm 2.19 \mathrm{mg} / \mathrm{gVS}$ from anaerobic digestion of Napier grass using micro oxygenation. Park et al. [12] reported that 8.12 $\mathrm{g} / \mathrm{L}$ of VFAs obtained from rice straw after 2 weeks of anaerobic fermentation with $\mathrm{NH}_{3}-\mathrm{N}$ and total-N content of $75.16 \mathrm{mg} / \mathrm{L}$ and $129.33 \mathrm{mg} / \mathrm{L}$, respectively.

Figure 2 shows the composition of VFAs produced from WOP and WNP. Results suggests that acetic, butyric and propionic acids were produced equally at the earlier stages (4 days); however, acetic acid was remained as most dominated thereafter followed by propionic and butyric acid. The composition of VFAs was 53.4 and $48.6 \%$ AA, 35.6 and $35.8 \%$ PA, and 11.0 and $17.3 \%$ BA with WOP and WNP, respectively. Our results are consistent compared to previous studies where a similar trend was observed with the dominance of acetic, propionic, and butyric acids during anaerobic digestion of various waste biomasses [12, 30].

\subsection{Lipid production utilizing VFAs produced from wastepaper}

Lipid production using the VFAs derived from anaerobic OCF of WOP and WNP was carried out by growing the oleaginous yeast, C. curvatus for $72 \mathrm{~h}$ at $30^{\circ} \mathrm{C}$ without any additional nutrients at a $\mathrm{C} / \mathrm{N}$ ratio of 40 . During the batch cultivation, cell biomass production was increased constantly from the beginning and reached maximum at 48 and $24 \mathrm{~h}$ with WOP and WNP, respectively (Fig.3 a \& b). Lipid accumulation was also increased with time and reached maximum at $48 \mathrm{~h}$ without any further increase. Biomass, lipid yield and lipid content achieved from the VFAs of WOP and WNP were $4.32 \pm 0.24$ and $2.91 \pm 0.23 \mathrm{~g} / \mathrm{L}, 1.78 \pm 0.12$ and $0.80 \pm$ $0.06 \mathrm{~g} / \mathrm{L}$, and $41.2 \pm 0.62$ and $27.7 \pm 0.36 \%$, respectively (Table 3 ). The lipid coefficient achieved was $0.11 \pm 0.02$ and $0.08 \pm 0.02 \mathrm{~g} / \mathrm{g}$ VFA with the productivity of $0.037 \pm 0.004$ and $0.033 \pm 0.006 \mathrm{~g} / \mathrm{L} / \mathrm{h}$ from VFAs of WOP and WNP, respectively. The results suggested that the 
231 cell biomass and lipid yield achieved from VFAs of WOP was comparatively higher than the

232 VFAs of WNP, due to the high yield of VFAs and compositional variation between WOP and

233 WNP. Xu et al. [4] achieved $2.5 \mathrm{~g} / \mathrm{L}$ biomass with lipid productivity of $0.272 \mathrm{~g} / \mathrm{L} / \mathrm{d}$ from $C$.

234 curvatus utilizing VFAs from anaerobic digestion of macroalgae.

The results of VFAs consumption during batch cultivation suggested that all of the three

236 VFAs were started to be utilized from the beginning of fermentation, and were completely

237 exhausted within 72 and $60 \mathrm{~h}$ with the VFAs of WOP and WNP, respectively (Fig. 4). The

238 results suggested that acetic acid was mainly utilized up to $36 \mathrm{~h}$ followed by butyric and

239 propionic acids. Though biomass and lipid production were increased with decreasing VFAs

240 concentration in the medium, rate of production was comparatively high during assimilation of

241 acetic acid than other VFAs. Previous studies also suggested that high proportion of acetic acid

242 was more advantageous for the synthesis of microbial lipids and cell mass production than

243 butyric and propionic acids [31, 32]. These results also indicated that C. curvatus is able to

244 utilize all three kinds of acid simultaneously, but preferably acetic acid than propionic and

245 butyric acids due to the variation in metabolic fate of each single VFAs [17, 33]. Acetic acid can

246 be directly transformed to acetyl-coenzyme A (CoA), which can be used to synthesize microbial

247 oils. Contrarily, propionate, an odd-chain carboxylic acid, is converted to propionyl CoA and

248 then enters the tricarboxylic acid (TCA) cycle via methylmalonyl-CoA interconversion to

249 succinyl-CoA. On the other hand, butyrate undergoes $\beta$-oxidation to produce acetoacetyl-CoA

250 which is further transformed into acetyl-CoA [17, 33].

251 3.5. Fatty acid profile of microbial lipids produced by C. curvatus utilizing VFAs 
Fatty acid profile analysis of the lipids produced by $C$. curvatus suggested that $\mathrm{C} 18$ fatty 253 acids (stearic, oleic, linoleic acid) were dominated (80\%), followed by C16 fatty acid (palmitic 254 acid) (15\%). The results suggested that the oleic acid (52.64 \pm 1.32 and $50.65 \pm 1.82 \%)$ was the 255 most abundant fatty acid followed by palmitic acid (16.42 \pm 1.16 and $15.18 \pm 0.82 \%)$, stearic 256 acid $(15.26 \pm 0.78$ and $14.41 \pm 0.69 \%)$ and linoleic acid $(12.25 \pm 0.82$ and $12.16 \pm 0.71 \%)$ in

257 lipids produced from VFAs of WOP and WNP, respectively. Several other studies were also 258 reported that palmitic acid, stearic acid, and oleic acid were the major fatty acids of lipids 259 produced by $C$. curvatus using VFAs derived from various sources $[4,12]$. Thus, the long chain 260 saturated and unsaturated fatty acids (C16 and C18) are the main components of the lipid, which 261 is similar to the typical plant/vegetable oils, suggesting its potential to use as a feedstock for 262 large scale production of biodiesel.

\section{Conclusions}

Utilization of wastepaper for production of microbial lipids to use as feedstock for

265 biodiesel aims to open new avenues for cost-effective production of biofuels through biorefinery 266 concept. Moreover, this biorefinery approach offers a potential valuable and alternative route for 267 management of wastepaper. Importantly, VFAs derived from wastepaper were used for lipid 268 production without the need to supply any additional nutrients. Biomass (4.3 g DCW/L) and lipid 269 accumulation (41\%) achieved in this study was comparatively higher than other studies utilizing 270 VFAs from various sources. Fatty acid profiles of lipids produced were comparable to 271 plant/vegetable oils used for biodiesel production, and hence, VFAs derived from wastepaper 272 could be a potential feedstock for microbial lipids production to use as non-edible lipid source 273 for biodiesel. However, further investigations will be needed to ensure process scale up 274 feasibility and sustainable production. 


\section{References}

[1] Cao X. Climate change and energy development: implications for developing countries. Resour Policy 2003; 29: 61-67. https://doi.org/10.1016/j.resourpol.2004.05.001.

[2] Chauhan SK, Shukla A. Environmental impacts of production of biodiesel and its use in transportation sector. In: Environmental Impact of Biofuels. InTech; 2011, p.1-18.

[3] Subramaniam R, Dufreche S, Zappi M, Bajpai R. Microbial lipids from renewable resources: production and characterization. J Ind Microbiol Biotechnol 2010; 37(12):1271-1287. https://doi.org/10.1007/s10295-010-0884-5.

[4] Xu X, Kim JY, Cho HU, Park HR, Park JM. Bioconversion of volatile fatty acids from macroalgae fermentation into microbial lipids by oleaginous yeast. Chem Eng J 2015; 264: 735-743. https://doi.org/10.1016/j.cej.2014.12.011.

[5] Meng X, Yang J, Xu X, Zhang L, Nie Q, Xian M. Biodiesel production from oleaginous $\begin{array}{lllll}\text { microorganisms. } & \text { Renew } & \text { Energy } & \text { 2009; }\end{array}$ https://doi.org/10.1016/j.renene.2008.04.014.

[6] Leiva- Candia DE, Pinzi S, Redel-Macias MD, Koutinas A, Webb C, Dorado MP. The potential for agro-industrial waste utilization using oleaginous yeast for the production of biodiesel. Fuel 2014; 123: 33-42. https://doi.org/10.1016/j.fuel.2014.01.054.

[7] Annamalai N, Sivakumar N, Oleskowicz - Popiel P. Enhanced production of microbial lipids from waste office paper by the oleaginous yeast Cryptococcus curvatus. Fuel 2018; 217 : 420-426. https://doi.org/10.1016/j.fuel.2017.12.108. 
295 [8] Ananthi V, Siva Prakash G, Chang SW, Ravindran B, Nguyen DD, Vo DVN, La DD, Bach

296

297

298

299

300

301

302

303

304

305

306

307

308

309

310

311

312

313

314

315

QV, Wong JWC, Gupta SK, Selvaraj A, Arun A. Enhanced microbial biodiesel production from lignocellulosic hydrolysates using yeast isolates. Fuel 2019; 256:115932. https://doi.org/10.1016/j.fuel.2019.115932.

[9] Fei Q, Chang HN, Shang L, Choi J d-r. Exploring low-cost carbon sources for microbial lipids production by fed-batch cultivation of Cryptococcus albidus. Biotechnol Bioprocess Eng 2011a; 16: 482-487. https://doi.org/10.1007/s12257-010-0370-y.

[10] Vajpeyi S, Chandran K. Microbial conversion of synthetic and food waste-derived volatile fatty acids to lipids. Bioresour Technol 2015; 188: 49-55. https://doi.org/10.1016/j.biortech.2015.01.099.

[11] Ahmad FB, Zhang Z, Doherty WOS, Teo VSJ, Hara IMO. Improved microbial oil production from oil palm empty fruit bunch by Mucor plumbeus. Fuel 2017; 194: 180187. https://doi.org/10.1016/j.fuel.2017.01.013.

[12] Park GW, Chang HN, Jung K, Seo C, Kim YC, Choi JH, Woo HC, Hwang I. Production of microbial lipid by Cryptococcus curvatus on rice straw hydrolysates. Process Biochem 2017; 56: 147-53. https://doi.org/10.1016/j.procbio.2017.02.020.

[13] Hii K, Baroutian S, Parthasarathy R, Gapes DJ, Eshtiaghi N. A review of wet air oxidation and thermal hydrolysis technologies in sludge treatment. Bioresour Technol 2014; 155 : 289-299. https://doi.org/10.1016/j.biortech.2013.12.066.

[14] Cho HU, Kim YM, Choi YN, Xu X, Shin DY, Park JM. Effects of pH control and concentration on microbial oil production from Chlorella vulgaris cultivated in the 
effluent of a low-cost organic waste fermentation system producing volatile fatty acids. Bioresour Technol 2015; 184: 245-250. https://doi.org/10.1016/j.biortech.2014.09.069.

[15] Jankowska E, Chwiałkowska J, Stodolny M, Oleskowicz-Popiel P. Effect of pH and retention time on volatile fatty acids production during mixed culture fermentation. Bioresour Technol 2015; 190: 274-280. https://doi.org/10.1016/j.biortech.2015.04.096.

[16] Lian J, Garcia-Perez M, Coates R, Wu H, Chen S. Yeast fermentation of carboxylic acids obtained from pyrolytic aqueous phases for lipid production. Bioresour Technol 2012; 118: 177-186. https://doi.org/10.1016/j.biortech.2012.05.010.

[17] Zheng Y, Chi Z, Ahring BK, Chen S. Oleaginous yeast Cryptococcus curvatus for biofuel production: ammonia's effect. Biomass Bioenerg 2012; 37: 114-121. https://doi.org/10.1016/j.biombioe.2011.12.022.

[18] Ruan ZH, Zanotti M, Zhong Y, Liao W, Ducey C, Liu Y. Co-hydrolysis of lignocellulosic biomass for microbial lipid accumulation. Biotechnol Bioeng 2013; 110: 1039-1049. https://doi.org/10.1002/bit.24773.

[19] Harde SM, Wang Z, Horne M, Zhu JY, Pan X. Microbial lipid production from SPORLpretreated Douglas fir by Mortierella isabellina. Fuel 2016; 175: 64-74. https://doi.org/10.1016/j.fuel.2016.02.023.

[20] Annamalai N, Al Battashi H, Nair AS, Al Azkawi A, Al Bahry S, Sivakumar N. Enhanced bioethanol production from waste paper through separate hydrolysis and fermentation. Waste Biomass Valori 2020; 11: 121-131. https://doi.org/10.1007/s12649-018-0400-0. 
[21] Huang C, Chen XF, Xiong L, Chen XD, Ma LL, Chen Y. Single cell oil production from low-cost substrates: the possibility and potential of its industrialization. Biotechnol Adv 2013; 31:129-139. https://doi.org/10.1016/j.biotechadv.2012.08.010.

[22] Nishimura H, Tan L, Sun ZY, Tang YQ, Kida K, Morimura S. Efficient production of ethanol from waste paper and the biochemical methane potential of stillage eluted from ethanol fermentation. Waste Manage 2016; 48(8): 644-651. https://doi.org/10.1016/j.wasman.2015.11.051.

[23] Wang L, Sharifzadeh M, Templer R, Murphy RJ. Bioethanol production from various waste papers: Economic feasibility and sensitivity analysis. Appl Energ 2013; 111: 1172-1182. https://doi.org/10.1016/j.apenergy.2012.08.048.

[24] APHA. Standard methods for the examination of water and wastewater, $20^{\text {th }}$ ed. American Public Health Association, Washington: DC, USA; 2008.

[25] Folch J, Lees M, Sloane-Stanley GH. A simple method for the isolation and purification of total lipids from animal tissues. J Biol Chem 1957; 226: 497-509.

[26] Fei Q, Chang HN, Shang LA, Choi JDR, Kim N, Kang J. The effect of volatile fatty acids as a sole carbon source on lipid accumulation by Cryptococcus albidus for biodiesel production. $\quad$ Bioresour Technol 2011b; 102: 2695-2701. https://doi.org/10.1016/j.biortech.2010.10.141.

[27] Yahara GA, Javier MA, Tulio MJM, Javier GR. Modeling of yeast Brettanomyces bruxellensis growth at different acetic acid concentrations under aerobic and anaerobic 
conditions. Bioprocess Biosys Eng 2007; 30: 389-395. https://doi.org/10.1007/s00449007-0135-y.

358

[28] Liu J, Yuan M, Liu JN, Lu LJ, Peng KM, Huang XF. Microbial conversion of mixed volatile fatty acids into microbial lipids by sequencing batch culture strategy. Bioresour Technol 2016; 222: 75-81. https://doi.org/10.1016/j.biortech.2016.09.100.

[29] Chang HN, Kim NJ, Kang JW, Jeong CM. Biomass-derived volatile fatty acid platform for fuels and chemicals. Biotechnol Bioprocess Eng 2010; 15: 1-10. https://doi.org/10.1007/s12257-009-3070-8.

[30] Sawatdeenarunat C, Sung S, Khanal SK. Enhanced volatile fatty acids production during anaerobic digestion of lignocellulosic biomass via micro-oxygenation. Bioresour Technol 2017; 237: 139-145. https://doi.org/10.1016/j.biortech.2017.02.029.

[31] Fontanille P, Kumar V, Christophe G, Nouaille R, Larroche C. Bioconversion of volatile fatty acids into lipids by the oleaginous yeast Yarrowia lipolytica. Bioresour Technol 2012; 114: 443-449. https://doi.org/10.1016/j.biortech.2012.02.091.

[32] Kolouchova I, Schreiberova O, Sigler K, Masak J, Rezanka T. Biotransformation of volatile fatty acids by oleaginous and non-oleaginous yeast species. FEMS Yeast Res 2015; 15: 76-84. https://doi.org/10.1093/femsyr/fov076.

[33] Fradinho JC, Oehmen A, Reis MAM. Photosynthetic mixed culture polyhydroxyalkanoate (PHA) production from individual and mixed volatile fatty acids (VFAs): substrate preferences and co-substrate uptake. J Biotechnol 2014; 185: 19-27. https://doi.org/10.1016/j.jbiotec.2014.05.035. 
378 
Table 1 Effect of initial concentrations and ratio of VFAs on biomass and lipid production (C/N ratio: 40 ). Results are presented using mean $\pm S D, n=3$

\begin{tabular}{lcccc}
\hline VFAs & Biomass $(\mathrm{g} / \mathrm{L})$ & Lipid yield $(\mathrm{g} / \mathrm{L})$ & Lipid content $(\%)$ & $Y_{x / s}(\mathbf{g} / \mathbf{g})$ \\
\hline Concentrations $(\mathbf{g} / \mathrm{L})$ & & & & \\
2 & $1.62 \pm 0.06$ & $0.587 \pm 0.004$ & $36.3 \pm 0.21$ & 0.294 \\
5 & $2.78 \pm 0.08$ & $0.781 \pm 0.008$ & $28.1 \pm 0.18$ & 0.156 \\
10 & $4.19 \pm 0.11$ & $0.712 \pm 0.005$ & $17.0 \pm 0.20$ & 0.071 \\
Ratio & & & & \\
$5: 1: 4$ & $3.62 \pm 0.10$ & $0.85 \pm 0.004$ & $23.6 \pm 0.23$ & 0.170 \\
$5: 2: 3$ & $3.78 \pm 0.08$ & $0.99 \pm 0.008$ & $26.2 \pm 0.18$ & 0.262 \\
$6: 2: 2$ & $4.16 \pm 0.12$ & $1.25 \pm 0.008$ & $30.1 \pm 0.22$ & 0.250 \\
$6: 1: 3$ & $4.38 \pm 0.08$ & $1.69 \pm 0.010$ & $38.6 \pm 0.19$ & 0.338 \\
\hline$Y$
\end{tabular}

$\mathrm{Y}_{x / s}-$ Lipid yield coefficient, g lipid/g VFAs 
Table 2 Effect of various nitrogen sources on biomass and lipid production using synthetic VFAs as carbon source at $5 \mathrm{~g} / \mathrm{L}$ (C/N ratio: 40$)$. Results are presented using mean $\pm \mathrm{SD}, \mathrm{n}=3$.

\begin{tabular}{|c|c|c|c|c|}
\hline Nitrogen sources & $\begin{array}{c}\text { Biomass } \\
(\mathrm{g} / \mathrm{L})\end{array}$ & $\begin{array}{c}\text { Lipid Yield } \\
(\mathrm{g} / \mathrm{L})\end{array}$ & $\begin{array}{c}\text { Lipid content } \\
(\%)\end{array}$ & $\begin{array}{c}Y_{x / s} \\
(g / g)\end{array}$ \\
\hline$\left(\mathrm{NH}_{4}\right)_{2} \mathrm{SO}_{4}$ & $3.60 \pm 0.13$ & $0.236 \pm 0.006$ & $6.5 \pm 0.18$ & $0.047 \pm 0.002$ \\
\hline $\mathrm{NH}_{4} \mathrm{Cl}$ & $3.69 \pm 0.14$ & $0.456 \pm 0.008$ & $12.4 \pm 0.08$ & $0.091 \pm 0.004$ \\
\hline $\mathrm{NH}_{4} \mathrm{NO}_{3}$ & $3.71 \pm 0.16$ & $0.416 \pm 0.006$ & $11.2 \pm 0.12$ & $0.083 \pm 0.006$ \\
\hline $\mathrm{NaNO}_{3}$ & $1.49 \pm 0.08$ & $0.256 \pm 0.005$ & $17.2 \pm 0.14$ & $0.051 \pm 0.004$ \\
\hline $\mathrm{KNO}_{3}$ & $1.36 \pm 0.08$ & $0.139 \pm 0.004$ & $10.2 \pm 0.08$ & $0.028 \pm 0.003$ \\
\hline Yeast extract (YE) & $3.24 \pm 0.15$ & $0.790 \pm 0.006$ & $24.4 \pm 0.16$ & $0.158 \pm 0.005$ \\
\hline Peptone & $4.17 \pm 0.12$ & $0.556 \pm 0.008$ & $13.3 \pm 0.10$ & $0.111 \pm 0.003$ \\
\hline$\left(\mathrm{NH}_{4}\right)_{2} \mathrm{SO}_{4}+\mathrm{YE}$ & $3.42 \pm 0.21$ & $0.360 \pm 0.004$ & $10.5 \pm 0.11$ & $0.072 \pm 0.004$ \\
\hline $\mathrm{NH}_{4} \mathrm{Cl}+\mathrm{YE}$ & $4.68 \pm 0.16$ & $0.828 \pm 0.006$ & $17.7 \pm 0.08$ & $0.166 \pm 0.006$ \\
\hline $\mathrm{NH}_{4} \mathrm{NO}_{3}+\mathrm{YE}$ & $5.53 \pm 0.09$ & $1.724 \pm 0.008$ & $31.2 \pm 0.13$ & $0.345 \pm 0.008$ \\
\hline $\mathrm{NaNO}_{3}+\mathrm{YE}$ & $0.76 \pm 0.05$ & $0.112 \pm 0.004$ & $14.7 \pm 0.10$ & $0.022 \pm 0.006$ \\
\hline $\mathrm{KNO}_{3}+\mathrm{YE}$ & $1.20 \pm 0.08$ & $0.199 \pm 0.006$ & $16.6 \pm 0.12$ & $0.040 \pm 0.002$ \\
\hline
\end{tabular}

$\mathrm{Y}_{\mathrm{x} / \mathrm{s}}$ - Lipid yield coefficient, g lipid / g VFAs 
Table 3 Biomass, lipid yield, lipid content, lipid coefficient and productivity of $C$. curvatus from VFAs derived from anaerobic open culture fermentation of waste office paper (WOP) and waste newspaper (WNP). Results are presented using mean $\pm \mathrm{SD}, \mathrm{n}=3$.

\begin{tabular}{cccccc}
\hline Substrate & $\begin{array}{c}\text { Biomass } \\
(\mathbf{g} / \mathbf{L})\end{array}$ & $\begin{array}{c}\text { Lipid yield } \\
(\mathbf{g} / \mathbf{L})\end{array}$ & $\begin{array}{c}\text { Lipid content } \\
(\mathbf{\%})\end{array}$ & $\begin{array}{c}\text { Lipid coefficient } \\
(\mathbf{g} / \mathbf{g} \text { VFA })\end{array}$ & $\begin{array}{c}\text { Lipid productivity } \\
\text { (g/L/h) }\end{array}$ \\
\hline WOP & $4.32 \pm 0.24$ & $1.78 \pm 0.12$ & $41.2 \pm 0.62$ & $0.11 \pm 0.02$ & $0.037 \pm 0.004$ \\
WNP & $2.91 \pm 0.23$ & $0.80 \pm 0.06$ & $27.7 \pm 0.36$ & $0.08 \pm 0.02$ & $0.033 \pm 0.006$ \\
\hline
\end{tabular}


Table 4 Fatty acid profile of lipids from volatile fatty acids (VFAs) derived from anaerobic open culture fermentation of waste office paper (WOP) and waste newspaper (WNP). Results are presented using mean $\pm \mathrm{SD}, \mathrm{n}=3$.

\begin{tabular}{ccc}
\hline \multirow{2}{*}{ Fatty acids } & \multicolumn{2}{c}{ VFAs } \\
\cline { 2 - 3 } & WOP & WNP \\
\hline Palmitic acid (C16:0) & $16.42 \pm 1.16$ & $15.18 \pm 0.82$ \\
Stearic acid (C18:0) & $15.26 \pm 0.78$ & $14.41 \pm 0.69$ \\
Oleic Acid (C18:1) & $52.64 \pm 1.32$ & $50.65 \pm 1.82$ \\
Linoleic acid (C18:2) & $12.25 \pm 0.82$ & $12.16 \pm 0.71$ \\
\hline
\end{tabular}




\section{Figure Captions}

Fig. 1 Total volatile fatty acids (TVFAs) production during anaerobic open culture fermentation (OCF) of waste office paper (WOP) and waste newspaper (WNP). Results are presented using mean $\pm S D, n=3$.

Fig. 2 Composition of volatile fatty acids (VFAs) produced during OCF of (a) waste office paper (WOP) and (b) waste newspaper (WNP). Results are presented using mean $\pm \mathrm{SD}, \mathrm{n}=3$. (PA: Propionic Acid, BA: Butyric acid, AA: Acetic acid)

Fig. 3 Biomass production, lipid yield and content during batch cultivation of C. curvatus from volatile fatty acids (VFAs) of waste office paper (WOP) and waste newspaper (WNP) from OCF. Results are presented using mean $\pm \mathrm{SD}, \mathrm{n}=3$.

Fig. 4 Consumption of each volatile fatty acids (VFAs) vs cell biomass production by $C$. curvatus utilizing VFAs of (a) waste office paper (WOP) and (b) waste newspaper (WNP). Results are presented using mean $\pm \mathrm{SD}, \mathrm{n}=3$. 


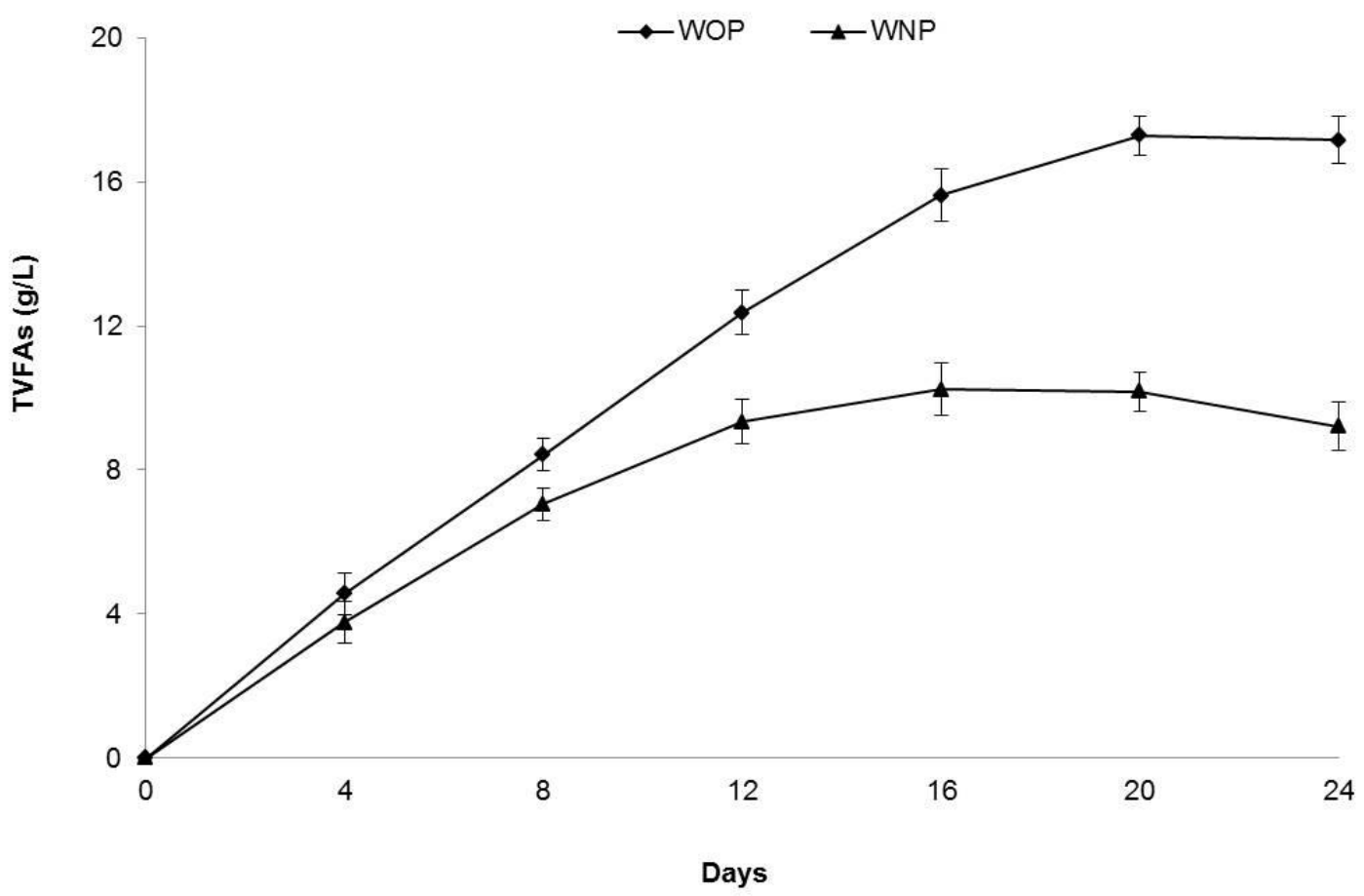

Fig. 1 


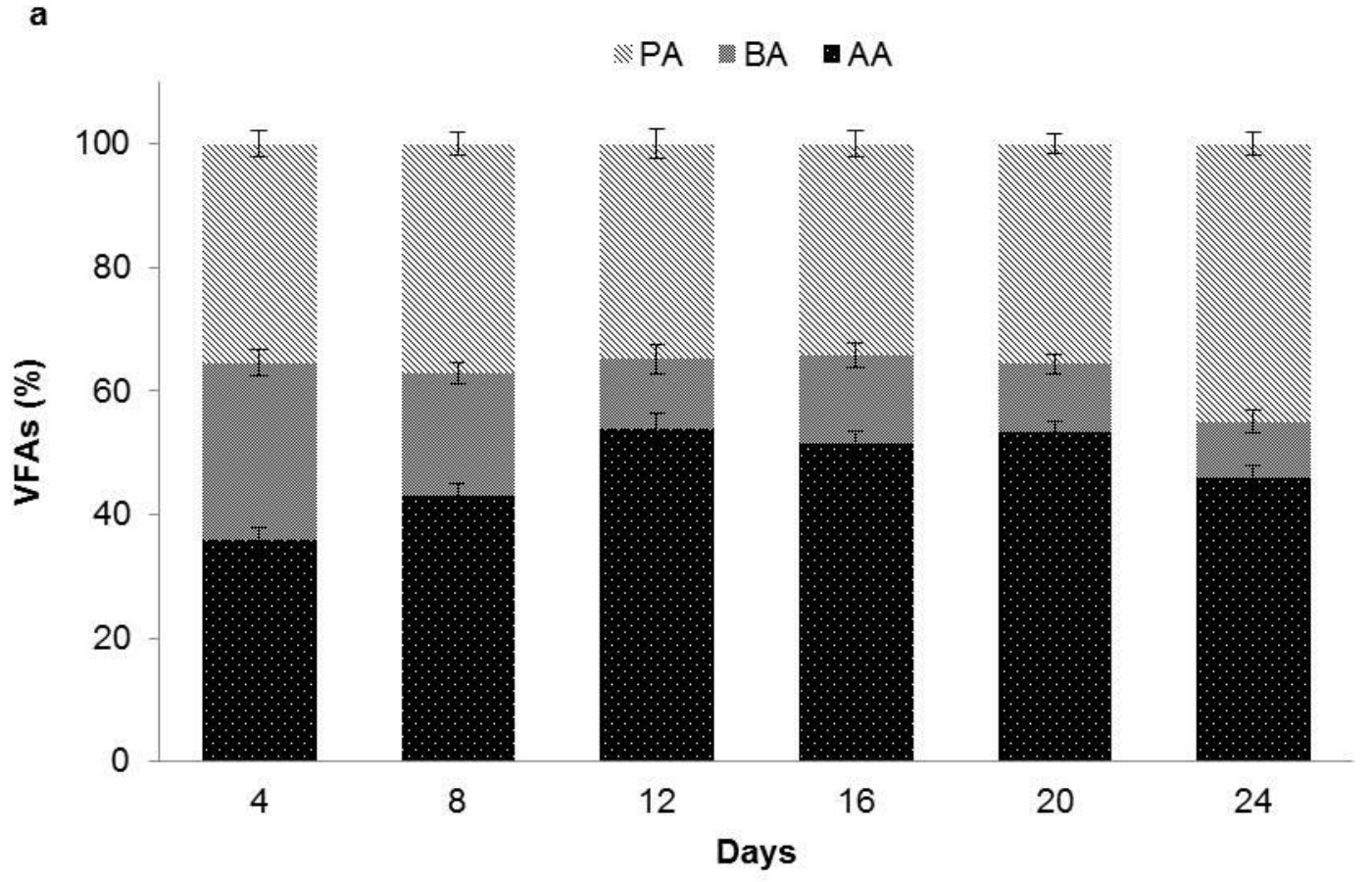

b

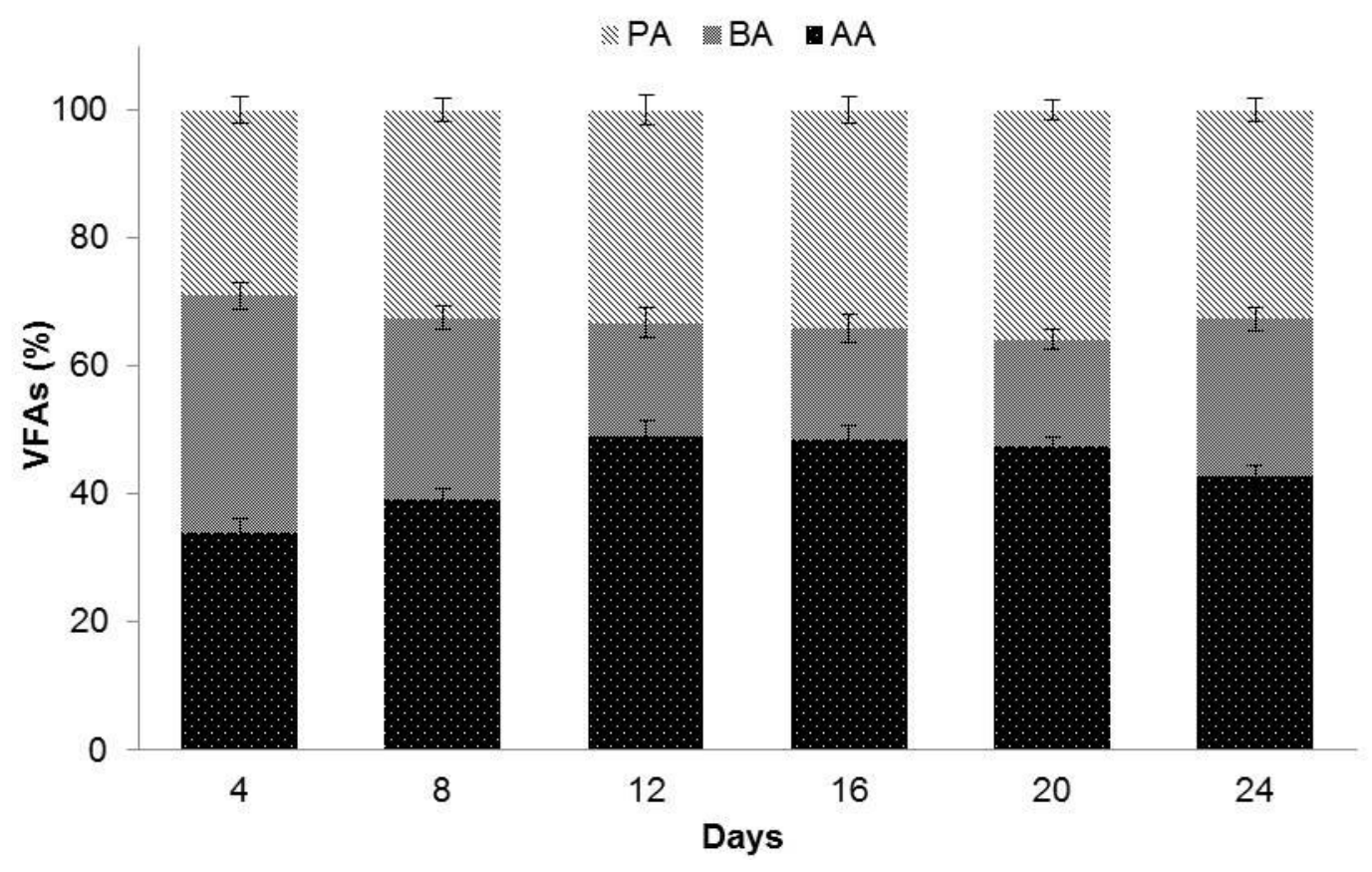

Fig. 2 

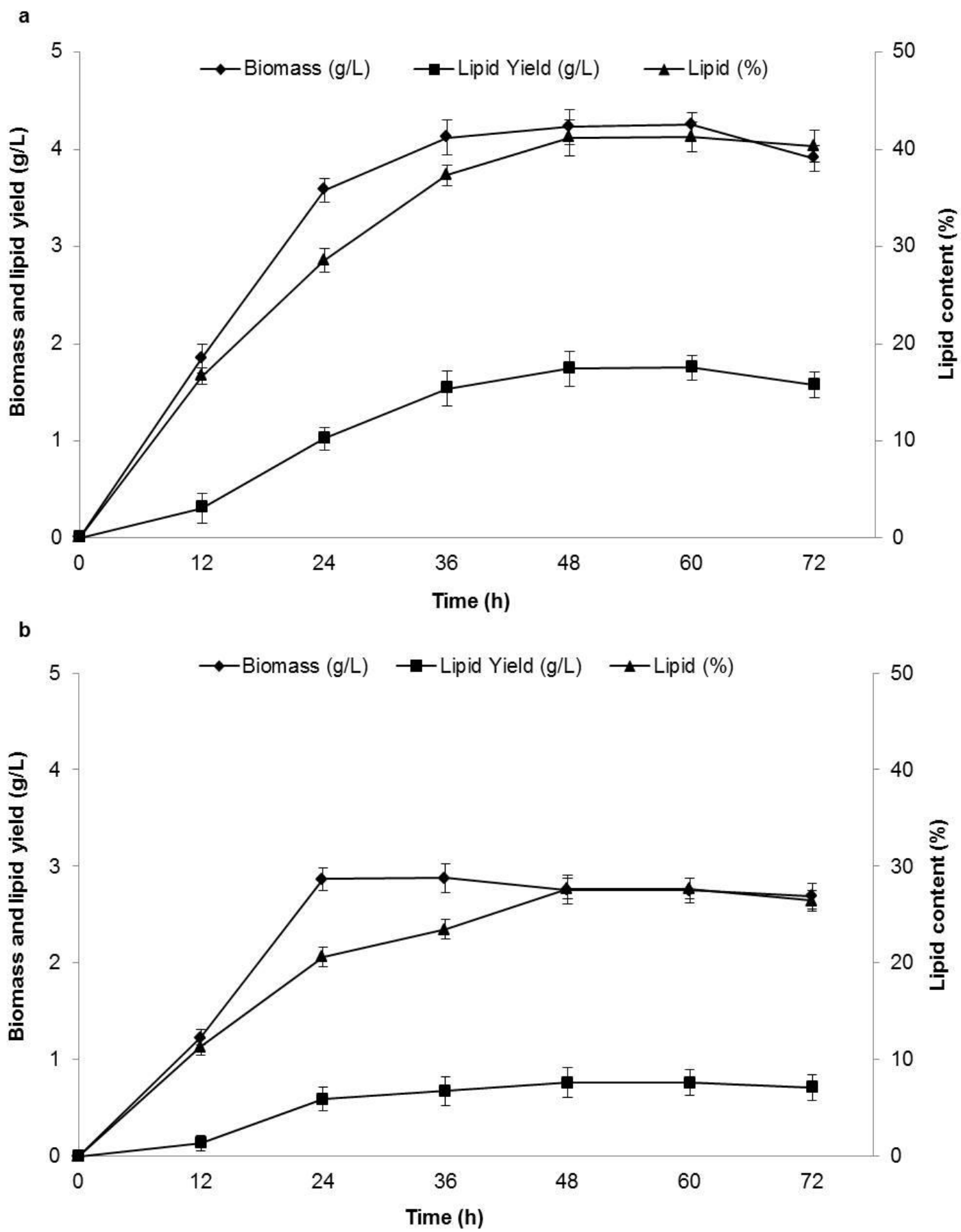

Fig. 3 
a

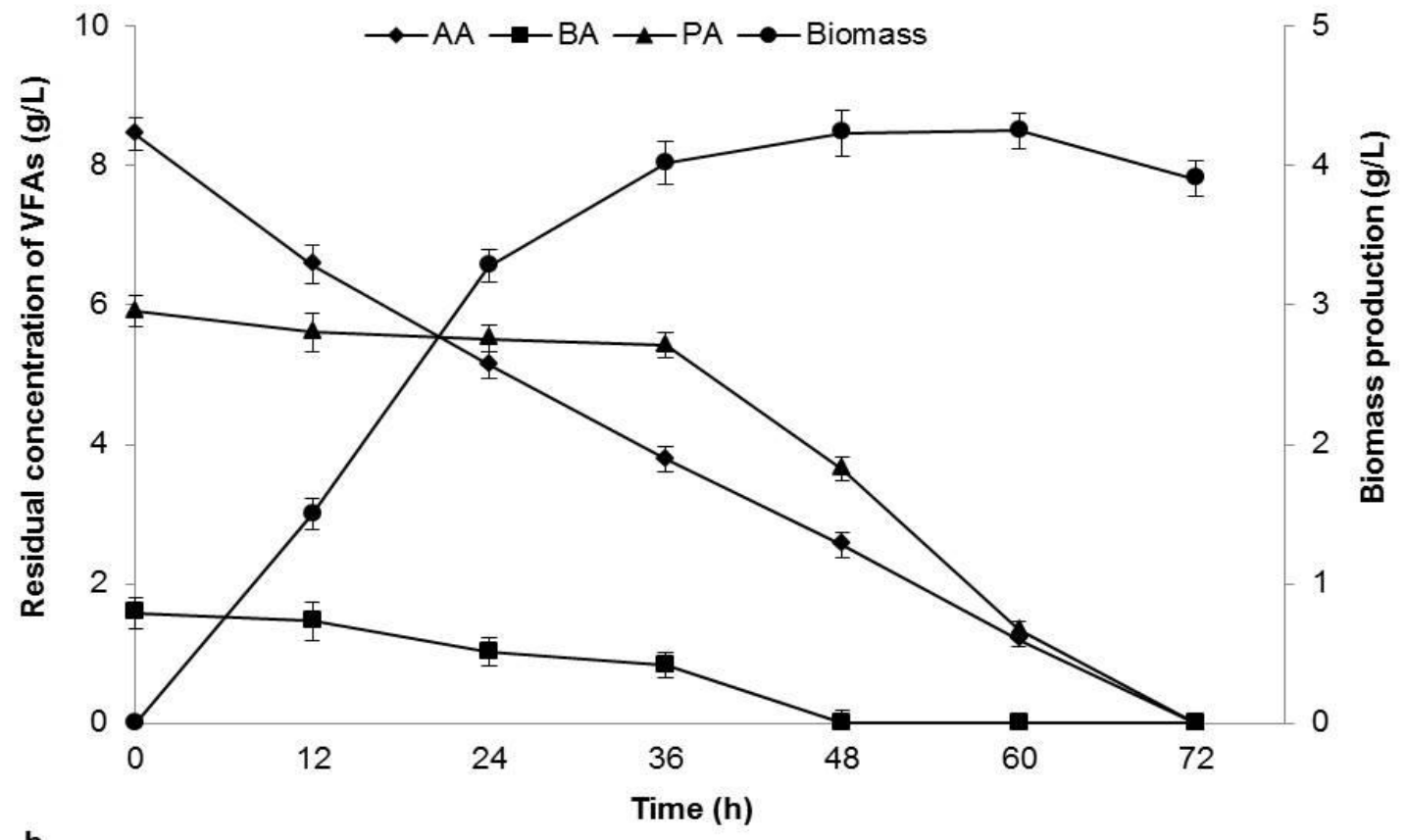

b

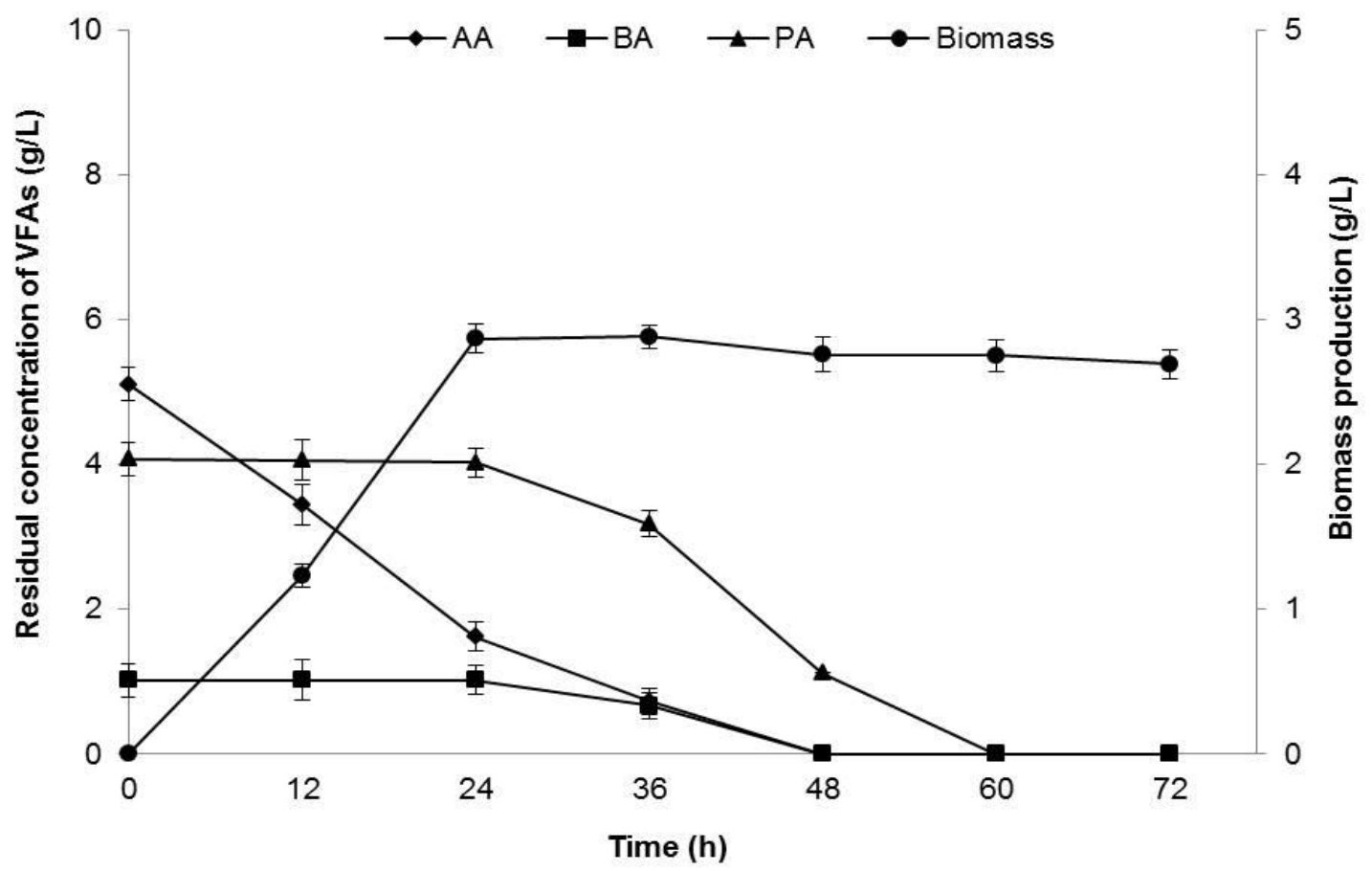

Fig. 4 


\section{$\underline{\text { Declaration of Interests }}$}

$>$ We, all the authors, declare that we have no known competing financial interests or personal relationships that could have appeared to influence the work reported in this paper. 


\section{CRediT Author Statement}

Neelamegam Annamalai: Design, Conceptualization, Methodology, Manuscript preparation, Revision, Nallusamy Sivakumar: Design and Supervision: Alfred Fernandez-Castane:

Design, Review and Editing, Piotr Oleskowicz-Popiel: Design, Review 